\title{
Entomopathogenic Nematodes (Nematoda: Rhabditida) in Slovenia: From Tabula Rasa to Implementation into Crop Production Systems
}

\author{
Žiga Laznik and Stanislav Trdan \\ University of Ljubljana, Biotechnical Faculty, Dept. of Agronomy, \\ Chair of Phytomedicine, Agricultural Engineering, Crop Production, \\ Pasture and Grassland Management, \\ Ljubljana
}

\section{Introduction}

The interest in the use of entomopathogenic nematodes as biological pest control agents has increased exponentially over the past decades. A hundred different laboratories explore these nematodes and their bacterial symbionts in more than 60 countries from every inhabited continent. Despite research breadth that extends from molecular biology to field ecology, the discipline is unified by common interest in biological control. Thirty years ago, the idea of using nematodes to control pest populations was vague promise held by the handful of researchers working with these obscure insect parasites. Today, they are no longer a laboratory curiosity but have begun to gain acceptance as environmentally benign alternatives to chemical insecticides. The entomopathogenic nematodes have proven particularly successful and are now commercially mass-produced in six of the seven continents to treat pest problems in agriculture, horticulture and human husbandry. The ease of mass production and exemption from registration requirenments are the two major reasons for early interest in the commercial developments of entomopathogenic nematodes. However, demonstrations of practical use, particularly in Europe and North America and subsuquently in Japan, China and Australia, spurred developments across the world that have led to the availability of nematodes against pests that were once thought impossible to control.

Studies of entomopathogenic nematodes (EPNs) are nonetheless in many countries of the world limited to laboratory work. The reason for this lies in the fact that nematodes are in such areas still regarded as the so-called alien species, since their presence has not been confirmed in natural environment. The first studies of EPNs in Slovenia began within the project L4-6477-0481-04 in 2004. In Slovenia the Rules on biological plant protection (2006) prohibit introduction of alien species into natural environment. Since until 2007 EPNs were in Slovenia considered as foreign species, all studies had been limited to laboratory experiments. Because we wanted to implement their use in food production in Slovenia, we decided to study the presence of EPNs also in our soil. After discovering these biological agents, Slovenia became one of the countries where the use of nematodes as means of biological protection is sanctioned by law also for outdoors application. 


\section{Entomopathogenic nematodes as biocontrol agents}

\subsection{Environmentally acceptable food production}

Integrated plant protection should not and cannot be equated with organic food production - which is according to some consumers the only way to produce healthy food. Consumers must be given opportunities to choose between organically produced food and food produced by other technologies, which imply less risk and lower costs. The state control system should ensure that food produced with the use of some synthetic substances is equally unblemished and healthy (Milevoj, 2002).

The most misgivings among consumers are caused by the use of products which protect plants against illnesses, harmful pests and weeds. The first principle of integrated protection is that food producers should use plant protection products only when other technological measures are no longer sufficient. In doing this only less toxic and faster degradable preparations are allowed. One of environmentally acceptable measures is also biological suppression of harmful pests on cultivated plants. Biological control is according to the definition of the International Organization for Biological and Integrated Control of Noxious Animals and Plants based on the use of living organisms (biological agents) or their products in order to prevent or diminish losses or damage caused to plants by harmful organisms. Biological control encompasses the so-called »beneficial organisms«. These are entomophagous insects which feed on phytophagous insects, mites and other Arthropoda, entomopathogenic microorganisms (fungi, bacteria, viruses, protozoa), which cause illnesses in pests harmful to plants and antagonists in the narrower sense (fungi, bacteria) controlling phytopathogenic microorganisms (Milevoj, 1998).

The use of biological preparations requires additional knowledge from users, as well as a keener environmental awareness. Biologically based preparations are ecologically more appropriate, while their activity is more specific, their formulation, application and precision in timing of treatments are more important. However, they are often not as efficient as chemical preparations (Milevoj, 2002).

\subsection{Entomopathogenic nematodes}

Entomopathogenic nematodes (EPNs) of the families Steinernematidae and Heterorhabditidae are lethal pathogens of insects. These pathogens contribute to the regulation of natural populations of insects, but the main interest in them is an inundatively applied biocontrol agent (Kaya and Gaugler, 1993). Their success in this role can be attributed to the unique partnership between a host-seeking nematode and a lethal insectpathogenic bacterium. Because of their biocontrol potential, considerable attention has been directed over the past few decades to genus Heterorhabditis and Steinernema and their respectative bacterial partners, Photorhabdus and Xenorhabdus (Forst and Clarke, 2002).

Although heterorhabditids and steinernematids are not closely related (Poinar, 1993), they have many features in common. These similarities, including their association with insectpathogenic bacteria, are presumed to have arison through convergent evolution (Poinar, 1993). In both Steinernema and Heterorhabditis there is a single free-living stage, the infective juvenile (IJ), that carries in its gut bacteria of the genus Xenorhabdus and Photorhabdus, respectively (Boemare et al., 1993). On encountering a suitable insect, the IJ enters through the mouth, anus or spiracles and makes its way to the haemocoel (Kaya and Gaugler, 1993). Some species may also penetrate through the intersegmental membranes of the insect cuticle. In the haemocoel, the IJ releases cells of its bacterial symbiont from its intestine. 
Bacteria multiply rapidly in haemolymph and produce toxins and other secondary metabolites, which contribute to the weakening of the host's defence mechanism. The host attacked by entomopathogenic nematodes usually dies because of poisoning or failure of certain organs in 24 to 72 hours after the infection (Forst and Clarke, 2002). Two developmental cycles thus occur in the host - that of nematodes and that of bacteria. The first generation nematodes pass into the second generation. After larvae cast off the fourth sheath and in the adult period, nematodes pass into the third generation, which thrives in the host as long as there is food. The host is by then already dead - killed by the toxins secreted by bacteria. The third generation nematodes are thus already saprophagic. Bacteria also produce such toxins (3.5 dihydroxy-4-isopropyl-stilben) which deter other micro organisms from settling in the carcass. When the developmental cycle is finished, nematodes leave the parts of carcasses which have not decomposed and they return into the ground. Nematodes cannot develop without a host (an insect) (Kaya and Gaugler 1993), without it they live in the ground for only a very brief period.

The importance of EPNs and biological plant protection against harmful organisms was first established in the USA in the thirties of the previous century. In 1923 Glaser and Fox discovered a nematode which attacked and caused death of the beetle Popillia japonica Newman (Glaser and Farell, 1935). Glaser introduced a method of growing EPNs »in vitro«. With such nematodes he was in 1939 carried out the first field experiment in New Jersey to suppress Popillia japonica (Kaya and Gaugler, 1993).

When entomopathogenic nematodes were first discovered, the hypothesis was proposed that nematodes alone cause death of the attacked insects. In 1937 Bovien first mentioned the possibility for the existence of symbiotic bacteria which live with entomopathogenic nematodes in a mutualist relationship. His hypothesis was in 1955 confirmed by Dutky and Weiser (Weiser, 1955). Boemare in 1982 proved that nematodes from the genus Steinernema produce toxic substances which negatively influence the immune system of infected insects and can themselves - without the presence of symbiotic bacteria - cause death of the host. For entomopathogenic nematodes from the genus Heterorhabditis it has not yet been established that they can alone produce toxic substances which would diminish the vitality of infected insects (Kaya and Gaugler, 1993).

The use of entomopathogenic nematodes in biological plant protection was some years ago still traditionally connected with suppressing soil-inhabiting insect pests (Ishibashi and Choi, 1991). The research results in the last two decades indicate they have also potential to suppress above-ground insect pests, but only in certain conditions (Trdan et al., 2008; Laznik et al., 2011). Lesser efficiency of entomopathogenic nematodes in suppression of aboveground insect pests is primarily due to inappropriate (insufficient) moisture, exposure to thermal extremes and ultraviolet radiation. These factors are of crucial importance for the survival of nematodes (Kaya and Gaguler, 1993). For this reason nematodes are less efficient against above-ground insect pests outdoors, though the previous laboratory tests showed much higher efficiency (Laznik et al., 2010c).

To lay nematodes on plants we can use equipment which is intended for spraying plant protection products, manuring or irrigation. For this purpose backpack manual or tractor sprayers, sprinklers and also planes are suitable. Infective larvae can be passed through spray tubes with diameter of at least $500 \mu \mathrm{m}$, capable to withstand pressure up to $2000 \mathrm{kPa}$ (Kaya and Gaugler, 1993).

EPN infective juveniles (IJs) can tolerate short-term exposure (2-24 hrs.) to many chemical and biological insecticides, fungicides, herbicides, fertilizers, and growth regulators, and can 
thus be tank-mixed and applied together (Koppenhöfer et al. 2002; De Nardo and Grewal 2003). Nematode-chemicals combinations in tank-mixes could offer a cost-effective alternative to foliar integrated pest management (IPM) systems.

Due to the sensibility of nematodes to ultraviolet radiation, they have to be applied to plants in the evening, early in the morning or in a cloudy weather, when the radiation is not so intense (Kaya and Gaugler, 1993). Nematode survival and efficacy on foliage has also been shown to be enhanced to varying degrees by addition of various adjuvants to the spray mixture, which have antidesiccant (e.g. glycerol, various polymers) or UV-protective (brighteners) actions (Grewal, 2002) although more needs to be done to enhance postapplication survival. The greatest potential for using EPNs against foliar pests is almost certainly in IPM programmes, in conjunction with other biocontrol agents (Sher and Parella, 1999) or selective chemicals (Rovesti and Deseo, 1990).

EPNs are considered exceptionally safe biological agents (Akhurst and Smith, 2002). Because their activity is specific, their environmental risk is considerably lower than that of chemical agents for plant protection. Since the first use of EPNs for suppressing Popillia japonica Newman in the USA (Glaser and Farrell, 1935) until now, no case of environmental damage due to these biological agents has been documented. The use of nematodes is safe for users. EPNs and their bacteria are not harmful for mammals and plants (Akhurst and Smith, 2002).

\section{Entomopathogenic nematodes as an exotic organisms in Slovenia}

The basis for regulating biological control of plants in Slovenia as an appropriate way to control harmful organisms in agriculture and forestry was provided by the Plant Health Act in 2001, which divided the management of this field between the Phytosanitary Administration of the Republic of Slovenia and the Ministry of the Environment and Spatial Planning, competent for the preservation of nature. The field is in more detail regulated by the Rules on biological plant protection (Official Gazette no. 45/06), which came into force on the $13^{\text {th }}$ of May 2006. The rules regulate introduction, cultivation and use of beneficial organisms, such as living natural enemies, antagonists, competitors or their products, and other organisms which are able to reproduce by themselves, including those which are packed or formulated as commercial products for biological protection of plants. The Rules' provisions do not apply to introduction and use of micro organisms which are covered by the regulations in the field of plant protection products. Beneficial organisms which can be used for biological protection of plants may be autochthonous (the species naturally present in a certain ecosystem) or allochthonous (the species which were introduced by man and which were before that not present in a certain ecosystem). The introduction of allochthonous organisms into nature requires special caution, so the application for introduction should be accompanied by risk assessment for nature - according to the regulation on risk assessment for nature. Only those allochthonous species which are on the list published by the Minister, in consensus with the Minister responsible for the preservation of nature, can be used for biological protection of plants in greenhouses and outdoors.

As already mentioned, the first studies of EPNs in Slovenia began in 2004. Until 2007 EPNs were considered allochthonous organisms, all our studies had been thus limited to laboratory experiments. The goal of the said studies was to investigate the effects different species of nematodes at different temperatures and concentrations of suspensions have on different species of harmful insects (Laznik and Trdan, 2008ab). The novelty in our approach 
was the selection of harmful pests, as we wanted to investigate the effects of EPNs on aboveground pests. In Slovenia this approach was for the first time used by Simona Perme (2005), who under the mentorship of Prof. Dr. Stanislav Trdan in her Master thesis studied the effects of EPNs on three species of harmful insects which cause damage by sucking or biting above-the-ground parts of plants.

The laboratory experiments in Slovenia thus tested the efficiency of EPNs against Colorado potato beetle (Leptinotarsa decemlineata [Say]) (Perme, 2005), greenhouse whitefly (Trialeurodes vaporariorum [Westwood]) (Perme, 2005), western flower thrips (Frankliniella occidentalis [Pergande]) (Perme, 2005), sawtoothed grain beetle (Oryzaephilus surinamensis [L.]) (Trdan et al., 2006), granary weevil (Sitophilus granarius [L.]) (Trdan et al., 2006), Hercinothrips femoralis (Reuter) (Trdan et al., 2007a), flea beetles (Phyllotreta spp.) (Trdan et al., 2008), cabbage stink bug (Eurydema ventrale Kolenati) (Zupančič, 2008), common cockchafer (Melolontha melolontha [L.]) (Laznik et al., 2009d), and cereal leaf beetle (Oulema melanopus [L.]) (Laznik et al., 2010b). These experiments confirmed the facts that had been already established, namely that EPNs are in optimal circumstances exceptionally efficient agents for suppressing harmful insects (Laznik and Trdan, 2008ab). Since we wanted to implement their use in food production in Slovenia, we decided to find out to what extent they are present in our soil.

\section{Establishing the presence of entomopathogenic nematodes in Slovenia}

\subsection{Recovery from soil}

Isolation of entomopathogenic nematodes from soil can be accomplished by standard extraction techniques for soil nematodes. Numerous nematodes are recovered, so entomopathogenic ones need to be separated and identified, a laborious procedure resulting in the processing of fewer samples compared with other methods (Kaya and Gaugler, 1993). Also, identification of the juveniles requires particular taxonomic expertise so only a few scientists are capable of the task. The alternative is to use a Galleria baiting technique which was used also in our experiments.

\subsubsection{Galleria baiting technique and White trap method}

The baiting technique with larvae of the greater wax moth, Galleria melonella (L.), is the method most commonly used for recovering infective-stage juveniles of entomopathogenic nematodes from soil (Bedding and Akhurst, 1975). The efficiency of this method had been increased using several consecutive baiting rounds (Fan and Hominick, 1991) and by baiting at two temperatures (Mráček and Bečváŕ, 2000).

The soil samples, five from each sampling place, were taken. Each soil sample (approximately $1 \mathrm{~kg}$ ) was a composite of 3 random subsamples taken at a depth of $3-15 \mathrm{~cm}$ in an area of $20 \mathrm{~m}^{2}$. The samples were taken at least $100 \mathrm{~m}$ apart at each site. The samples were placed in polyethylene bags to prevent water loss and were kept in coolers (ca. $15^{\circ} \mathrm{C}$ ) during transit to the laboratory. We put a living larva of a greater wax moth into an Eppendorf tube which had been pierced. In each soil sample 5 insect host Eppendorf tubes were placed. Mortality of G. melonella was assessed after 5 days. Dead Galleria larvae were used for culturing on a water trap to obtain infective juveniles. The dead larvae of a greater wax moth were dried at room temperature for 10 days. Dead insects were incubated individually in modified »White traps (White, 1929) which consisted of a glass Petri dish (9 $\mathrm{cm}$ in a diameter) filled with destilated water to a depth of $0.5 \mathrm{~cm}$. The bottom of an inverted 
Petri dish ( $3 \mathrm{~cm}$ in a diameter) was placed in the bigger Petri dish. A sheet of filter paper was placed on the smaller Petri dish allowing the edge of the paper to come in a contact with the destilated water. The dead larvae were placed on the filter paper and incubated at room temperature until all the nematode progeny had emerged and moved down into the water of the bigger Petri dish. Following procedure contained the use of centrifuge and $5 \%$ concetration of sodium hypoclorate. The aim of this process was to get infective juveniles from the suspension. With the received suspension we infected artificialy larvae of greater wax moth again. The harvested infective juveniles (IJs) were stored at $4{ }^{\circ} \mathrm{C}$ in distilled water (Laznik et al., 2008, 2009abc).

\subsubsection{Molecular characterization}

To confirm the identification of the isolated nematodes harvested from the larvae of the greater wax moth, a molecular characterization was conducted. Genomic DNA was extracted from individual nematodes and PCR was performed to multiply the ITS region using the primers TW81 and AB28, following Hominick et al. (1997). The PCR products were re-isolated from a 1 $\%$ TAE-buffered agarose gel using the E.Z.N.A. Gel Extraction Kit (Omega Bio-Tek, USA). The re-isolated sample was sequenced in the laboratory of the Agricultural Biotechnology Centre in Gödöllő, Hungary. The sequence was submitted to GenBank public database. The sample DNA sequence was compared to the sequences of the species Steinernema and Heterorhabditis using a BLAST search at the National Centre for Biotechnology Information (NCBI) web site (www.ncbi.nlm.nih.gov) (Laznik et al., 2008, 2009abc).

\subsection{Distribution of entomopathogenic nematodes in Slovenia}

Between the years 2006 and 2009 we analysed 570 soil samples from 114 different locations in Slovenia. The samples has been taken especially in areas that are considered suitable habitats (e.g. sandy soils, cultivated fields, grasslands, forests) for the presence of steinernematids and heterorhabditids. The presence of EPNs was confirmed in 31 samples, which is $5.4 \%$ of the total number of the analysed soil samples (Laznik et al., 2008, 2009abc).

\subsubsection{Steinernema affine Bovien}

In the year 2007 we recorded the species Steinernema affine Bovien (Laznik et al., 2008) of the Steinernematidae family, which is in the intermedium group of nematodes (Bovien, 1937). It lives in symbiosis with the bacteria Xenorhabdus bovienii Akhurst (Poinar, 1988). The said organism was first found in 1937, while its usefulness in biological plant protection was discovered a few years ago (Willmott et al., 2002). This species often appears in soils where plants of the family Brassicaceae are cultivated (Nielsen and Philipsen, 2004). Cabbage was cultivated also in the field located not far from Staro selo near Kobarid, where we confirmed the presence of the said nematodes. Steinernema affine is known to be exceptionally efficient biological agent for suppressing cabbage root fly (Delia radicum [L.]) (Willmott et al., 2002; Nielsen and Philipsen, 2004). Cabbage is in Slovenia the most widely cultivated vegetable (24.1\% of all fields or 871 ha) (the Statistical Office of the Republic of Slovenia, 2005), which makes the said plant from the family Brassicaceae even more useful.

\subsubsection{Steinernema feltiae (Filipjev)}

The most frequently (15 positive samples) encountered species of EPNs in Slovenia was Steinernema feltiae (Filipjev) (accesion no: EU914855; http:/ / blast.ncbi.nlm.nih.gov/Blast.cgi) 
(Laznik et al., 2009a). In Slovenia it was found in Notranjska, Dolenjska and Prekmurje. The said species is in the so-called "feltiae group «, in which the length of the IJ ranges from 700 to $1000 \mu \mathrm{m}$. S. feltiae lives in symbiosis with the bacteria Xenorhabdus bovienii Akhurst (Poinar, 1988), and was first discovered as late as in 1934. Its usefulness in biological control is well known (Trdan et al., 2006). Some researchers report that S. feltiae, S. intermedium and S. affine are likely to appear on cultivated land (Sturhan, 1996). In our study we came to a similar conclusion only in one of the positive samples (the strain B30, which was found on a field near Cerknica), while all other strains were found on uncultivated areas (forests, meadows) (Laznik et al., 2009a). In Europe S. feltiae has been so far confirmed in 24 countries and is considered one of the most widely spread species of EPNs (Hominick, 2002). After our finding the said species became autochthonous in Slovenia and can be used also outdoors to suppress harmful insects (Decision ..., 2008a).

\subsubsection{Steinernema carpocapsae Weiser}

The second most spread species of EPNs in Slovenia (confirmed in 12 soil samples) was Steinernema carpocapsae Weiser (accesion no: EU914854; http://blast.ncbi.nlm.nih.gov /Blast.cgi) (Laznik et al., 2008). The species belong to the so-called »carpocapsae group«, IJs of these are below $600 \mu \mathrm{m}$ and live in symbios with the bacteria Xenorhabdus nematophila Poinar \& Thomas (Akhurst, 1980). It was first found in 1955, in Europe is present in 15 countries (Hominick, 2002). Since it can be relatively easily multiplied and can endure several months in total desiccation, it is massively used in plant protection (Kaya and Gaugler, 1993). It acquires hosts by passive ambush and is for this reason used for suppressing more mobile insect species (Campbell et al., 2003). Its optimal temperature interval is between 22 and $28{ }^{\circ} \mathrm{C}$. The abovementioned species became autochthonous in Slovenia on the $1^{\text {st }}$ of September 2008 (Conclusion ..., 2008b).

\subsubsection{Steinernema kraussei Steiner}

In the Gorenjska region (the north-west region of Slovenia) we discovered in two samples also Steinernema kraussei Steiner (accession no.: EU914856; http://blast.ncbi.nlm.nih.gov /Blast.cgi) (Laznik et al., 2009b), which is characteristically active also at slightly lower temperatures (between 6 and $10^{\circ} \mathrm{C}$ ). The said species belongs to the so-called »feltiae group « and lives in symbiosis with the bacteria Xenorhabdus bovienii Akhurst (Fischer-Le Saux et al., 1998). S. kraussei was the first species to be found in the world, discovered in 1923 (Glaser and Fox, 1930). The species served in the first field experiment (in 1939) suppressing the beetle Popillia japonica Newman. Many researchers confirmed high efficiency of this species at low tempetrature (Long et al., 2000; Willmott et al., 2002), what is of great importance for suppression of harmful insects outdoors since thermal extremes, UV radiation levels and lack of moisture importantly influence EPNs activity (Kaya and Gaugler, 1993). This species also was in Slovenia listed as autochthonous organism for biological protection of plants (Conclusion ..., 2009a).

\subsubsection{Heterorhbaditis bacteriophora Poinar}

In August 2008 in the Dravograd region (the north-east Slovenia) the presence of Heterorhabditis bacteriophora Poinar was confirmed (accession no.: FJ477060; http://blast.ncbi.nlm.nih.gov/Blast.cgi) (Laznik et al., 2009c). It is so far the only found nematode from the genus Heterorhabditis in Slovenia. In Europe 4 species from the said 
genus have been discovered so far, the said species is in Europe present in 12 countries (Hominick, 2002). The infective larvae of H. bacteriophora range from 520 to $600 \mu \mathrm{m}$. The nematode acquires hosts actively by detecting vapourised substances (released $\mathrm{CO}_{2}$ ) (O'Halloran in Burnell, 2002). The species has great potential in biological plant protection (Koppenhöfer et al., 2004; Grewal et al., 2005). In Slovenia the said species became autochthonous on the $15^{\text {th }}$ of January 2009 (Conclusion ..., 2009b) on the basis of the application for changing the status of allochthonous organism submitted by the Biotechnical Faculty on the $6^{\text {th }}$ of January 2009 to the Ministry of Agriculture, Food, and Forestry of the Republic of Slovenia - the Phytosanitary Administration of the Republic of Slovenia. The status of autochthonous species was in the same way acquired by the S. feltiae, S. kraussei in S. carpocapsae.

\section{Laboratory experiments}

\subsection{In vivo production of the EPNs}

For laboratory use and small-scale field testing, in vivo production of entomopathogenic nematodes (EPN) is the appropriate method. When it comes to commercial use of EPN at a larger scale for international markets, in vitro production is currently the only economically reasonable means to supply EPN at high quality and at reasonable costs. In vivo production method for culturing EPN in insect hosts have been reported by various authors (Flanders et al., 1996). These references essentially describe systems based on the White trap (White, 1929), which take advantage of the infective juvenile's (IJ) natural migration away from host cadaver upon emergence. The most common insect host used for in vivo production is the last instar of the greater wax moth (Galleria melonella), because of its high susceptibility to most nematodes, ease in rearing, wide availability and ability to produce high yields (Ehlers, 2001). After 2-5 days, infected larvae of the greater wax moth are transferred to the White traps. Following harvest, concentration of nematodes can be accomplished by gravity settling (Flanders et al., 1996). Following procedure contained the use of centrifuge and $5 \%$ concetration of sodium hypoclorate. The aim of this process was to get infective juveniles from the suspension.

\subsection{Preparing the concentration of nematode suspension}

We tested the efficacy of the EPNs in controlling different stages (larvae, adults) of a different insect species by exposing individuals to either 0, 250, 500, 1000, or 2000 IJ/individual. We determined the number of infective juveniles (IJs) in a previously (see above) prepared unknown concentration of nematode suspension by counting the number of such in droplets $(5 \mu \mathrm{l} \times 5)$ and by diluting (adding M9 solution) or by concentrating (reduction to an adequate volume with the assistance of centrifugation). In this manner we obtained the selected concentrations of nematode suspensions $(0,2500,5000,10000$, and $20000 \mathrm{IJ} / \mathrm{ml}$ ). We used only infective juveniles which were less than 2 weeks old. During the experiment, which was repeated three times, we stored the infective juveniles at $4{ }^{\circ} \mathrm{C}$ (Laznik et al., 2010a).

\subsection{Laboratory bioassay}

We carried out the experiment according to the procedure described in the paper of Trdan et al., 2006. The following procedure was performed with a time interval in three replications. We placed tested insect species in glassy Petri dishes (diameter $=9 \mathrm{~cm}$ ) with 
each containing 10 individuals. Prior to this, we put filter paper into each Petri dish (the same diameter as the former Petri dish) and some additional food (specific for the tested insect). Each treatment in the experiment was repeated 10 times. The assigned nematode concentration was added to the filter paper with a pipette $(1 \mathrm{ml})$. The Petri dishes were put in a rearing chamber (type: RK-900 CH, producer: Kambič Laboratory equipment, Semič, Slovenia) with a volume of $0.868 \mathrm{~m}^{3}$ (width $\times$ height $\times$ depth $=1000 \times 1400 \times 620 \mathrm{~mm}$ ). We tested the efficacy at different temperatures $\left(15,20,25\right.$, and $\left.30^{\circ} \mathrm{C}\right)$ and at a relative humidity of $80 \%$. The number of dead individuals was determined $2,4,6$, and 8 days after treatment. The dead individuals were dissected to determine if the nematodes were present. In such a manner we wanted to prove that the insects died due to the EPNs' activity.

\subsection{Statistical analysis}

A multifactor analysis of variance (ANOVA) was conducted to determine the differences in mortality rates (\%) between tested insect species reared in different treatments. Before the analysis, the mean mortality was tested for the homogeneity of treatment variances. Mortality rate data were corrected for control mortality, using Abbott's formula (Abbott, 1925). The arcsine square-root was transformed before this analysis. A Student-NewmanKeuls multiple range test $(P \leq 0.05)$ was used to separate mean differences among the parameters in all the treatments. For the last days after treatment (DAT) the values of $\mathrm{LC}_{50}$ and $\mathrm{LC}_{90}$ (the numbers of IJs/individual causing $50 \%$ and $90 \%$ mortality) were estimated, and the overall efficacy of the tested nematodes was determined from this estimates (Trdan et al., 2008; Laznik et al., 2010a) All statistical analyses were performed using Statgraphics Plus for Windows 4.0 (Manugistics, Rockville, MD, USA) and the figures were created with MS Office Excel 2003. The data were presented as untransformed means $\pm S E$.

\section{Greenhouse experiment}

\subsection{Greenhouse experiment design - testing EPNs activity against western flower thrips and greenhouse whitefly on greenhouse-grown cucumbers}

Location, production of the seedlings, types of substrates, and experimental design is detailed described in the paper published by Trdan et al. 2007a. The glasshouse temperature at the time of the experiment was $26.0-45.5^{\circ} \mathrm{C}$ (8:00 a.m. - 20:00 p.m.) and $14.0-25.0{ }^{\circ} \mathrm{C}$ (21.00 p.m. - 7:00 a.m.), while the relative humidity was 17.5 - $68.0 \%$ (8:00 a.m. - 20:00 p.m.) and $55.0-90.0 \%$ (21.00 p.m. - 7:00 a.m.). Four cucumber plants in each sleeve (sub-plot) were sprayed with a suspension of commercial EPN. A standard rate of $2500 \mathrm{IJ}$ per $\mathrm{ml}$ of water was used. Four plants were sprayed with insecticide, and the four control plants were sprayed with water. Before spraying each suspension of nematodes, $0.05 \%$ of the surfactant Nu-Film-17 (a.i. di-1-p-methene, 96 \%; manufacturer: Lances Links SA, Geneva, Switzerland; supplier: Karsia Dutovlje d.o.o., Ljubljana, Slovenia) was added to the sprayer to enable the suspension to move more effectively across the leaf surface (Trdan et al. 2007a, Laznik et al., 2011).

Weekly applications thereafter $(1,2,3,4$, and 5 weeks after first application [AFA]) of entomopathogenic nematodes suspension (at glasshouse temperature) were made by an injector hollow cone nozzle TVI 8002 attached to motor operated backpack sprayer (Trdan et al. 2007a). Sprays with insecticide were applied at the same time of the day (early evening) using a backpack sprayer with an injector nozzle ID 9002 (Trdan et al. 2007a). For more detailed information see Trdan et al., 2007a and Laznik et al., 2011. 


\subsection{Observations and evaluations}

Evaluations were taken at three time-points during the growing season ( 3,5 and 7 AFA). At each time-point, three randomly selected plants of about the same height in each sub-plot were assessed for the number of the tested insect. Three leaves (lower, middle and upper part) from each chosen plant were evaluated.

Cucumber fruits were harvested when their diameters were $3-4 \mathrm{~cm}$. The yield was classified into three groups according to harvest time (up to 3 AFA, between 3 and 5 weeks AFA and 5 weeks AFA). The cucumber yield was determined in two ways: 1) mass of fruits per plant, and 2) number of fruits per plant (Trdan et al. 2007a). Data analyses was made according to Trdan et al. 2007a.

\section{Field experiment}

\subsection{Field experiment design - testing EPNs activity against Colorado potato beetle in potato}

Experimental field $(45 \times 11 \mathrm{~m})$ was divided into four blocks, and in each there were six treatments: control (unsprayed), domestic strain of EPN low conc., domestic strain of EPN high conc., commercial strain of EPN low conc., commercial strain of EPN high conc., and insecticide. The size of each treatment parcel was $20.9 \mathrm{~m}^{2}(5.5 \times 3.8 \mathrm{~m})$. Agri-technical measures are detailed desribed in Laznik et al. 2010c.

We applied EPNs using the backpack sprayer Solo 425. The jet stream nozzle number 04F110 with a pressure of 2 bars was used. Two concentrations of nematode suspension for the foliar application against Colorado potato beetle were chosen: low at $250.000 \mathrm{IJ} \mathrm{m}^{-2}$ and high at $500.000 \mathrm{IJ} \mathrm{m}^{-2}$. The application of all treatments were repeated, but only with half the concentration of nematode suspension (125.000 $\mathrm{IJ} \mathrm{m}^{-2}$ and $\left.250.000 \mathrm{IJ} \mathrm{m}^{-2}\right)$. For both applications $0.05 \%$ of the surfactant $\mathrm{Nu}-\mathrm{Film}-17$ (a.s. di-1-p-methene, $96 \%$; manufacturer: Lances Links SA, Geneva, Switzerland; supplier: Karsia Dutovlje d.o.o., Ljubljana, Slovenia) was added to EPNs' suspension, enabling the suspension to move more effectively across the leaf surface. We observed the population dynamics of Colorado potato beetle on day of application - (0 DAT), 3, 10, 16, 19 and 26 days after treatment (DAT). A visual inspection was made on the five selected plants in each treatment and the different developmental stages of $\mathrm{CPB}$ were counted throughout the course of the experiment.

The potatoes were harvested with a back output machine with two rolling plates on 12 August 2008 and on 6 August 2009. On the day of harvest the tubers were classified with a special shaking device into three fractions: fraction 1 (tubers $<4 \mathrm{~cm}$ ), fraction 2 (tubers between 4 and $5 \mathrm{~cm}$ ), and fraction 3 (tubers $>5 \mathrm{~cm}$ ) and weighed them separately as well as together. Later we calculated this to the $\mathrm{t} \mathrm{ha}^{-1}$.

\subsection{Preparation of the EPNs}

Commercial product was purchased (Koppert B.V., Berkel en Rodenrijs, The Netherlands) through the importer Zeleni hit d.o.o. (Ljubljana, Slovenia). The domestic nematode isolate was produced in a mechanically stirred, internal loop bioreactor with an $8000 \mathrm{ml}$ capacity (BR021, Inel Ltd., Budapest, Hungary). After sterilization, the bioreactor containing the P2 culture media (23g yeast extract, $12.5 \mathrm{~g}$ dried egg yolk, $5 \mathrm{~g} \mathrm{NaCl}$ and $40 \mathrm{ml}$ corn oil in $1000 \mathrm{ml}$ water, Chavarria-Hernandez and de la Torre, 2001) was inoculated with $100 \mathrm{ml}$ of overnight bacterial symbiont culture, isolated from infective juveniles of the domestic strain. The temperature was $20^{\circ} \mathrm{C}$, and the aeration rate was 1.0 
vvm. After two days, when the oxygen consumption of the bacterial culture decreased, the bioreactor was inoculated with five million infective juveniles of the domestic strain in $500 \mathrm{ml}$ of culture media. The nematodes were harvested 14 days after, when the total number of nematodes was 25.000 individuals per $\mathrm{ml}$, and the ratio of infective juveniles was $95 \%$. The nematodes were centrifugated and washed twice with sterilized tap water, and were stored in sterile $\mathrm{M} 9$ solution $\left(5 \mathrm{~g} \mathrm{NaCl}, 3 \mathrm{~g} \mathrm{KH}_{2} \mathrm{PO}_{4}\right.$ and $6 \mathrm{~g} \mathrm{Na}_{2} \mathrm{HPO}_{4}$ in $1000 \mathrm{ml}$ water).

\subsection{Statistical analysis}

Differences in the numerous developmental stages of the insect (egg clusters, larvae, adults) between individual treatments, as well as differences in yield were analysed with the use of ANOVA. Prior to analysis, each variable was tested for homogeneity of variance, and the data found to be non-homogenous was transformed to $\log (\mathrm{Y})$ before ANOVA. Significant differences $(\mathrm{P} \leq 0.05)$ between mean values were identified using Student-Newman-Keuls's multiple range test. All statistical analyses were done using Statgraphics Plus for Windows 4.0 (Statistical Graphics Corp., Manugistics, Inc.). The data was presented as untransformed means \pm SE (Laznik et al., 2010c).

\section{Activity of entomopathogenic nematodes against selected pests of ornamental plants and vegetables in greenhouses and domestic environment}

\subsection{Hercinothrips femoralis (Reuter)}

In the laboratory experiment we studied the efficiency of Steinernema feltiae and Heterorhabditis bacteriophora for suppressing banded greenhouse thrips - Hercinothrips femoralis (Trdan et al., 2007b). At foliar application of the suspension with the concentration $200 \mathrm{IJ} /$ specimen both species were relatively efficient at suppressing larvae and adult specimens of banded greenhouse thrips, though they were markedly more successful in suppressing larvae. Both species of nematodes reached the highest efficiency at $25^{\circ} \mathrm{C}$, while independently of temperature and nematodes species the average corrected mortality rates in larvae was $37.7 \%$, in adult specimens only $15.4 \%$ (Trdan et al., 2007b). In view of the previous research results (Chyzik et al., 1996; Premachandra et al., 2003) we expected different efficiency of both biological agents in suppression of banded greenhouse thrips. The unexpected lesser efficiency of $H$. bacteriophora can be in this experiment attributed to the specific strain of the researched nematodes. The same species of EPNs are isolated in different parts of the world, while the results of many studies show that different nematode races of the same species differ considerably in their efficiency to suppress harmful pests (Premachandra et al., 2003). Chyzik et al. (1996) found out, among other things, that H. bacteriophora strain HP88 is very efficient in suppressing banded greenhouse thrips, while the other strain (IS5) of the same species is much less efficient. Similar results were produced also by some other studies (Premachandra et al., 2003).

\subsection{Western flower thrips (Frankliniella occidentalis [Pergande])}

In a greenhouse experiment, the effectiveness of Steinernema feltiae (Filipjev) (Rhabditida: Steinernematidae) was compared with abamectin for the control of western flower thrips (Frankliniella occidentalis [Pergande], Thysanoptera, Thripidae), on slicer cucumbers. In a 
period from mid June to end of August, cucumbers were grown in four different growth substrates: expanded perlite, expanded vermiculite, light expanded clay aggregate and peat. A suspension of entomopathogenic nematodes (2500 infective juveniles/ml) was applied to cucumber leaves nine times in one growing season, whilst insecticide at recommended dose (22.5 g a.i./ha) was used three times. A significant effect in the extent of pest damage to the leaves (assessed by a six grade scale) was determined only for type of suppression (nematodes, insecticide, and untreated control), but not type of growth substrate nor damage evaluation date (16 July, 3 August, and 23 August). The leaves of cucumbers treated with nematodes and insecticide were significantly less damaged than untreated plants, with damage never exceeding $10 \%$ of the leaf surface. Nevertheless, type of growth substrate showed a significant effect on the number of fruits as well as on the mean mass of fruits. Light expanded clay aggregate was seen to be the least appropriate growth substrate, whilst the other three substrates can all be recommended for cucumber growing. The mean mass of fruits was also significantly influenced by type of suppression, with the mean mass of fruits in treated plants being significantly higher (from 37 up to $51 \%$ ) than in untreated plants. The mean number of fruits per plant did not differ significantly between different types of pest suppression. Nine times spraying with nematodes and three times spraying with abamectin showed about the same efficacy against western flower thrips on greenhouse-grown slicer cucumbers (Trdan et al., 2007b).

\subsection{Greenhouse whitefly (Trialeurodes vaporariorum [Westwood])}

The greenhouse whitefly (Trialeurodes vaporariorum [Westwood]) (GWF) is an important polyphagous harmful pest on cultivated plants (Vet et al., 1980). Adult specimens and larvae are harmful because they feed on plant sap, excrete honeydew and carry certain plant viruses (Coffin and Coutts, 1995). Because of excessive and inexpedient use of insecticides the said species developed resistance to some active substances (Gorman et al., 2001), so biological protection represents one of the alternative solutions for protecting plants against the said harmful pests. Some previous studies have shown that foliar application EPNs is inefficient for suppressing the selected harmful pests (Hara et al., 1993), some recent studies, however, have shown that we can by appropriate applying and by optimising the method of EPNs application successfully suppress also aboveground pests (Trdan et al., 2007a; Laznik et al., 2010c). The results of our study (Table 1) have shown that adult specimens of $T$. vaporariorum are sensitive to the activity of EPNs (Laznik et al., 2011). We expect that satisfactory mortality rates of insects are the result of applying EPNs several times in a row. When applying EPNs several times in a row, one should of course take into account the economic aspect of food production (Athanassiou et al., 2010; Laznik et al., 2010c). The results of our study have shown that feeding of adult specimens of the greenhouse whitefly influences also the average mass of cucumbers (table 2) (Laznik et al., 2011). The mass was importantly influenced by the manner in which the cultivated cucumbers were protected, while different substrates were in this regard of no consequence. A related study came to similar conclusions (Tocucumbersu and Abe, 2005). The smallest yield of cucumbers was in our study found on expanded clay, which was confirmed also by several other related studies (Cantliffe et al., 2003; Trdan et al., 2007a). 
Entomopathogenic Nematodes (Nematoda: Rhabditida)

\begin{tabular}{|c|c|c|c|c|c|c|c|c|}
\hline \multirow[b]{2}{*}{ year } & \multirow[b]{2}{*}{$\begin{array}{c}\text { Time } \\
\text { point } \\
\text { (weeks } \\
\text { AFA) }\end{array}$} & \multicolumn{4}{|c|}{ Substrates } & \multicolumn{3}{|c|}{ Control methods } \\
\hline & & $\begin{array}{l}\text { Expanded } \\
\text { perlite }\end{array}$ & $\begin{array}{l}\text { Vermi- } \\
\text { culite }\end{array}$ & $\begin{array}{c}\text { Light } \\
\text { expanded } \\
\text { clay } \\
\text { aggregate }\end{array}$ & Peat & Untreated & $\begin{array}{c}\text { thia- } \\
\text { methoxam }\end{array}$ & EPNs \\
\hline \multirow{3}{*}{2007} & 3 & $3.00 \pm 0.47 a$ & $\begin{array}{l}4.22 \pm \\
0.48 b\end{array}$ & $\begin{array}{l}5.94 \pm \\
1.63 b\end{array}$ & $\begin{array}{c}23.61 \pm \\
7.71 \mathrm{c}\end{array}$ & $\begin{array}{c}21.13 \pm \\
5.83 c\end{array}$ & $\begin{array}{c}2.58 \pm \\
0.38 \mathrm{a}\end{array}$ & $\begin{array}{l}3.88 \pm \\
0.66 \mathrm{~b}\end{array}$ \\
\hline & 5 & $\begin{array}{c}25.89 \pm \\
4.24 \mathrm{a}\end{array}$ & $\begin{array}{c}56.56 \pm \\
9.80 \mathrm{~b}\end{array}$ & $\begin{array}{c}41.33 \pm \\
8.94 \mathrm{~b}\end{array}$ & $\begin{array}{c}83.94 \pm \\
15.33 c\end{array}$ & $\begin{array}{l}96.46 \pm \\
11.26 \mathrm{c}\end{array}$ & $\begin{array}{c}34.58 \pm \\
4.52 \mathrm{~b}\end{array}$ & $\begin{array}{c}24.75 \pm \\
4.35 \mathrm{a}\end{array}$ \\
\hline & 7 & $\begin{array}{l}58.22 \pm \\
16.21 \mathrm{a}\end{array}$ & $\begin{array}{l}51.28 \pm \\
16.32 \mathrm{a}\end{array}$ & $\begin{array}{c}58.78 \pm \\
8.08 \mathrm{a}\end{array}$ & $\begin{array}{l}74.68 \pm \\
13.18 \mathrm{a}\end{array}$ & $\begin{array}{c}119.17 \pm \\
11.77 \mathrm{C}\end{array}$ & $\begin{array}{c}25.64 \pm \\
5.27 \mathrm{a}\end{array}$ & $\begin{array}{c}39.46 \pm \\
7.38 b\end{array}$ \\
\hline \multirow{2}{*}{2008} & 1 & $\begin{array}{l}34.33 \pm \\
23.14 \mathrm{a} \\
\end{array}$ & $\begin{array}{l}38.56 \pm \\
10.66 \mathrm{ab}\end{array}$ & $\begin{array}{l}43.56 \pm \\
21.41 \mathrm{ab}\end{array}$ & $\begin{array}{l}74.78 \pm \\
25.12 \mathrm{~b} \\
\end{array}$ & $\begin{array}{l}89.00 \pm \\
21.62 b\end{array}$ & $\begin{array}{l}36.25 \pm \\
15.83 \mathrm{a} \\
\end{array}$ & $\begin{array}{c}18.17 \pm \\
7.26 \mathrm{a} \\
\end{array}$ \\
\hline & 2 & $\begin{array}{l}32.00 \pm \\
14.10 \mathrm{a}\end{array}$ & $\begin{array}{l}67.67 \pm \\
28.22 \mathrm{ab}\end{array}$ & $\begin{array}{c}109.22 \pm \\
43.31 b\end{array}$ & $\begin{array}{l}74.56 \pm \\
10.01 b\end{array}$ & $\begin{array}{c}128.50 \pm \\
33.00 \mathrm{~b}\end{array}$ & $\begin{array}{l}51.25 \pm \\
13.30 \mathrm{a}\end{array}$ & $\begin{array}{c}32.83 \pm \\
9.53 \mathrm{a}\end{array}$ \\
\hline
\end{tabular}

* Means with the same letter in the same line are not significantly different at $P=0.05$ (StudentNewman-Keuls's multiple range test).

Table 1. Mean number of GWF adults per plant in 2007 and 2008 at different control methods and growth substrates.

\begin{tabular}{|c|c|c|c|c|c|c|c|c|}
\hline \multirow[b]{2}{*}{ year } & \multirow[b]{2}{*}{$\begin{array}{c}\text { Time } \\
\text { point } \\
\text { (weeks } \\
\text { AFA) }\end{array}$} & \multicolumn{4}{|c|}{ Substrates } & \multicolumn{3}{|c|}{ Control methods } \\
\hline & & $\begin{array}{l}\text { Expanded } \\
\text { perlite }\end{array}$ & $\begin{array}{l}\text { Vermi- } \\
\text { culite }\end{array}$ & $\begin{array}{c}\text { Light } \\
\text { expanded } \\
\text { clay } \\
\text { aggregate }\end{array}$ & Peat & Untreated & $\begin{array}{c}\text { thia- } \\
\text { methoxam }\end{array}$ & EPNs \\
\hline \multirow{3}{*}{2007} & 3 & $\begin{array}{c}217.60 \pm \\
10.75 a\end{array}$ & $\begin{array}{c}312.52 \pm \\
19.83 c\end{array}$ & $\begin{array}{c}260.12 \pm \\
22.01 b\end{array}$ & $\begin{array}{c}261.73 \pm \\
15.39 b\end{array}$ & $\begin{array}{c}229.91 \pm \\
12.92 \mathrm{a}\end{array}$ & $\begin{array}{c}276.73 \pm \\
17.47 \mathrm{~b}\end{array}$ & $\begin{array}{c}276.88 \pm \\
14.86 \mathrm{~b}\end{array}$ \\
\hline & 5 & $\begin{array}{c}279.43 \pm \\
17.73 a\end{array}$ & $\begin{array}{c}294.50 \pm \\
15.36 \mathrm{a}\end{array}$ & $\begin{array}{c}286.19 \pm \\
26.22 \mathrm{a}\end{array}$ & $\begin{array}{c}292.19 \pm \\
19.52 \mathrm{a}\end{array}$ & $\begin{array}{c}254.35 \pm \\
11.83 a\end{array}$ & $\begin{array}{c}290.69 \pm \\
14.79 b\end{array}$ & $\begin{array}{c}326.04 \pm \\
20.74 c\end{array}$ \\
\hline & 7 & $\begin{array}{c}300.07 \pm \\
17.56 \mathrm{a}\end{array}$ & $\begin{array}{c}282.86 \pm \\
20.58 \mathrm{a}\end{array}$ & $\begin{array}{c}287.08 \pm \\
23.09 a\end{array}$ & $\begin{array}{c}322.11 \pm \\
34.29 a\end{array}$ & $\begin{array}{c}242.53 \pm \\
18.55 a\end{array}$ & $\begin{array}{c}285.48 \pm \\
18.72 b\end{array}$ & $\begin{array}{c}340.59 \pm \\
21.38 \mathrm{c}\end{array}$ \\
\hline \multirow{2}{*}{2008} & 1 & $\begin{array}{c}237.62 \pm \\
9.47 \mathrm{a}\end{array}$ & $\begin{array}{c}295.56 \pm \\
8.75 c\end{array}$ & $\begin{array}{l}277.91 \pm \\
16.27 \mathrm{bc}\end{array}$ & $\begin{array}{c}262.72 \pm \\
15.97 \mathrm{~b}\end{array}$ & $\begin{array}{c}228.48 \pm \\
9.47 \mathrm{a}\end{array}$ & $\begin{array}{c}288.60 \pm \\
11.52 b\end{array}$ & $\begin{array}{c}288.1 \pm \\
11.13 \mathrm{~b}\end{array}$ \\
\hline & 2 & $\begin{array}{c}270.36 \pm \\
12.45 \mathrm{a}\end{array}$ & $\begin{array}{c}290.61 \pm \\
8.71 b\end{array}$ & $\begin{array}{l}271.63 \pm \\
15.69 \mathrm{ab}\end{array}$ & $\begin{array}{c}265.00 \pm \\
15.25 \mathrm{a}\end{array}$ & $\begin{array}{c}211.51 \pm \\
6.46 \mathrm{a}\end{array}$ & $\begin{array}{c}310.69 \pm \\
10.27 b\end{array}$ & $\begin{array}{c}301.68 \pm \\
10.17 b\end{array}$ \\
\hline
\end{tabular}

* Means with the same letter in the same line are not significantly different at $P=0.05$ (StudentNewman-Keuls's multiple range test).

Table 2. Mean mass of cucumbers (g) in 2007 and 2008 at different control methods and growth substrates.

\section{Activity of entomopathogenic nematodes against selected field crop pests}

\subsection{Flea beetles (Phyllotreta spp.)}

Although flea beetles (Phyllotreta spp., Coleoptera, Chrysomelidae) are among more important harmful pests for the family Brassicaceae, in Europe as well as on some other continents EPNs have so far not been used to suppress them (Trdan et al., 2008). In 2005, four entomopathogenic nematode species (Steinernema feltiae, S. carpocapsae, Heterorhabditis bacteriophora, and $H$. megidis) were tested under the laboratory conditions with the aim of 
studying their activity in controlling adult flea beetles, Phyllotreta spp. Activity of the biological agents studied was determined at three different concentrations (200, 1000, and 2000 IJs per adult) and temperatures $\left(15,20\right.$, and $\left.25^{\circ} \mathrm{C}\right)$. Mortality of the beetles was determined 2, 4, 6, and 8 days after treatment. Efficacy of the nematodes was higher at the 20 and $25^{\circ} \mathrm{C}$ than at $15^{\circ} \mathrm{C}$. At $20^{\circ} \mathrm{C}$, eight days after treatment the nematodes killed from $43.5 \%$ (H. megidis at the lowest concentration) up to $77 \%$ (S. feltiae at the lowest concentration) of the beetles. At $25^{\circ} \mathrm{C}$, three nematode species (S. feltiae, S. carpocapsae, and H. bacteriophora) killed at least $74 \%$ of the beetles at both higher concentrations. Steinernema feltiae was the most efficient at the lowest temperature $\left(\mathrm{LC}_{50}=483-1467 \mathrm{IJ}\right.$ s/adult), and it is therefore considered to have the highest potential for the control of overwintered flea beetles (May) in the open as alternative to chemical insecticides. The nematodes S. feltiae, $S$. carpocapsae and $H$. bacteriophora proved themselves to be the most appropriate choice for controlling the adult flea beetles during warm summer months, when in Slovenia the pest occur in the highest numbers (Trdan et al., 2008).

\subsection{Eurydema ventrale Kolenati}

Cabbage stink bugs (Eurydema ventrale Kolenati) appear on different species of the family Brassicaceae. They cause damage primarily to young plants. Until recently, it was common practice to suppress stink bugs with chemical insecticides if they attacked massively (Maceljski et al., 2004).

Our study found out that EPNs can be efficient in suppression of stink bugs. Different factors influence the efficiency of nematodes. We found out that the efficiency of nematodes in suppression of stink bugs depends on the species and the concentration of nematode suspension, temperature, developmental stage of stink bugs and the time passed after the application. Nematodes were more efficient at higher temperatures $\left(25^{\circ} \mathrm{C}: 34 \%\right)$ than at lower $\left(20^{\circ} \mathrm{C}: 13 \% ; 15^{\circ} \mathrm{C}: 5 \%\right)$. Steinernema feltiae at $15{ }^{\circ} \mathrm{C}$ and $20^{\circ} \mathrm{C}$ showed the highest efficiency $(57 \%)$ in suppressing larvae of stink bugs. This cannot be confirmed for suppressing adult specimens of the harmful pest, since Steinernema carpocapsae was at $15{ }^{\circ} \mathrm{C}$ and $20{ }^{\circ} \mathrm{C}$ more successful $(30 \%)$. Nematodes were on average more efficient $(23 \%)$ at higher (2000 IJs/specimen) than at lower concentration (200 IJs/specimen; 13 \%) (Zupančič, 2008).

\subsection{Colorado potato beetle (Leptinotarsa decemlineata [Say])}

The Colorado potato beetle (Leptinotarsa decemlineata [Say]) is in the majority of European countries still the most important harmful pest on potato (OEPP/EPPO, 1997). Larvae and adult specimens feed on foliage and thus retard development of plants. The first generation specimens are particularly harmful, so their economic threshold of harmfulness is less lower than the second generation specimens (Maceljski et al., 2004). The effect of EPNs on Colorado potato beetles has not been much researched in Europe. The results of our study (Trdan et al., 2009) show that both environmental temperature and the developmental stage of Colorado potato beetles importantly influence the efficiency of EPNs in suppression of this harmful pest. The lowest temperature, $15^{\circ} \mathrm{C}$, in this regard proved least appropriate, while at the temperatures 20 and $25{ }^{\circ} \mathrm{C}$ the efficiency EPNs was highest, which coincides with the results of our previous studies (Trdan et al., 2006), as well with the results of studies by other authors (Kaya and Gaugler, 1993). If we want to suppress the first (hibernated) adult specimens of the Colorado potato beetle by foliar application of the studied biological 
agents - this is lately becoming widely-spread in suppression of harmful insects (Broadbent and Olthof, 1995) - it is advisable to apply a suspension of $S$. feltiae at higher concentrations. This species in our study at $15^{\circ} \mathrm{C}$ displayed the highest efficiency in suppression of adult specimens. When the first adult specimens appeared (the second half of May), nights in the region where we conducted the experiment are relatively fresh. Young larvae were at the lowest temperature most sensitive to nematodes, and they were first to react to nematodes at all temperatures. Older larvae were in this regard slightly less sensitive, yet still more than adult specimens - entomopathogenic nematodes are known to be more efficient with larvae than adult specimens (Trdan et al., 2009) because they more easily penetrate the former than the latter (LeBeck et al., 1993).

After Steinernema feltiae became autochthonous in Slovenia, we carried out the first field experiment with their use in Slovenia - for suppressing the Colorado potato beetle Leptinotarsa decemlineata (Say) (Laznik et al., 2010c). In our previous laboratory study we confirmed that EPNs are efficient biological agent for suppressing the said harmful insects (Trdan et al., 2009). The results of our study have shown that the Slovenian strain Steinernema feltiae (B30) and the commercial preparation Entonem (S. feltiae) are efficient biological agents for suppressing above-ground insects, particularly larvae stages, of Colorado potato beetles outdoors. Though some previous laboratory studies confirmed efficiency of EPNs also with adult specimens of Colorado potato beetles (Stewart et al., 1998; Trdan et al., 2009), the results of laboratory experiments can be hardly compared with those which are obtained outdoors (Cantelo and Nickle, 1992).

The results of our study have shown that the activity of EPNs on younger larvae at high concentrations is similarly fast as with the insecticide thiamethoxam, while the activity of nematodes on older larvae was delayed. EPNs and the insecticide thiamethoxam in our experiment did not displayed apparent activity, which had been already established by many other researchers (Armer et al., 2004; Hoffmann et al., 2008). The concentration of nematode suspension did not influence the larvae's and adult specimens' mortality rates, which is favourable from the aspect of economical use of the said biological agents in integrated food production as the costs of suppression of harmful pests with EPNs are proportionate with the quantity of used EPNs. That is precisely why we during the second repetition decided to apply halved concentration of nematode suspension. The influence of concentration of nematodes suspension on the mortality rates of insects can be explained by the fact that only a few IJs suffice to cause the insect's death (Bednarek and Nowicki, 1986; Arthurs et al., 2004). Despite lower price of EPNs during our second application, the ratio between the price of thiamethoxam/ha in comparison with the price of EPNs / ha remained 1:142.

In connection with changes in the population of Colorado potato beetles in our experiment we studied also the influence of the harmful pest on the mass of yield. The yield was in the year 2008 (Figure 1) larger than in the year 2009 (Figure 2), primarily as the consequence of planting our own seed material (Milošević et al., 2008). In comparison with some related studies, which researched the mass of yield of the Kondor potato (Ábrahám et al., 2006), we achieved lesser results, which can be to a large extent attributed to great population pressure of Colorado potato beetles in our experiment. No differences in influence on total tuber yield were found between individual treatments with EPNs. The mass of yield was also not influenced by the concentration of nematode suspension, which coincides with the fact that the population dynamics of larvae and adult specimens in our experiment, which 
influence defoliation of potato plants most (Hare, 1980), was not affected by the concentration of nematode suspension. It is known that total defoliation of potato plants can cause more than $50 \%$ loss of yield (Cranshaw and Redcliff, 1980).
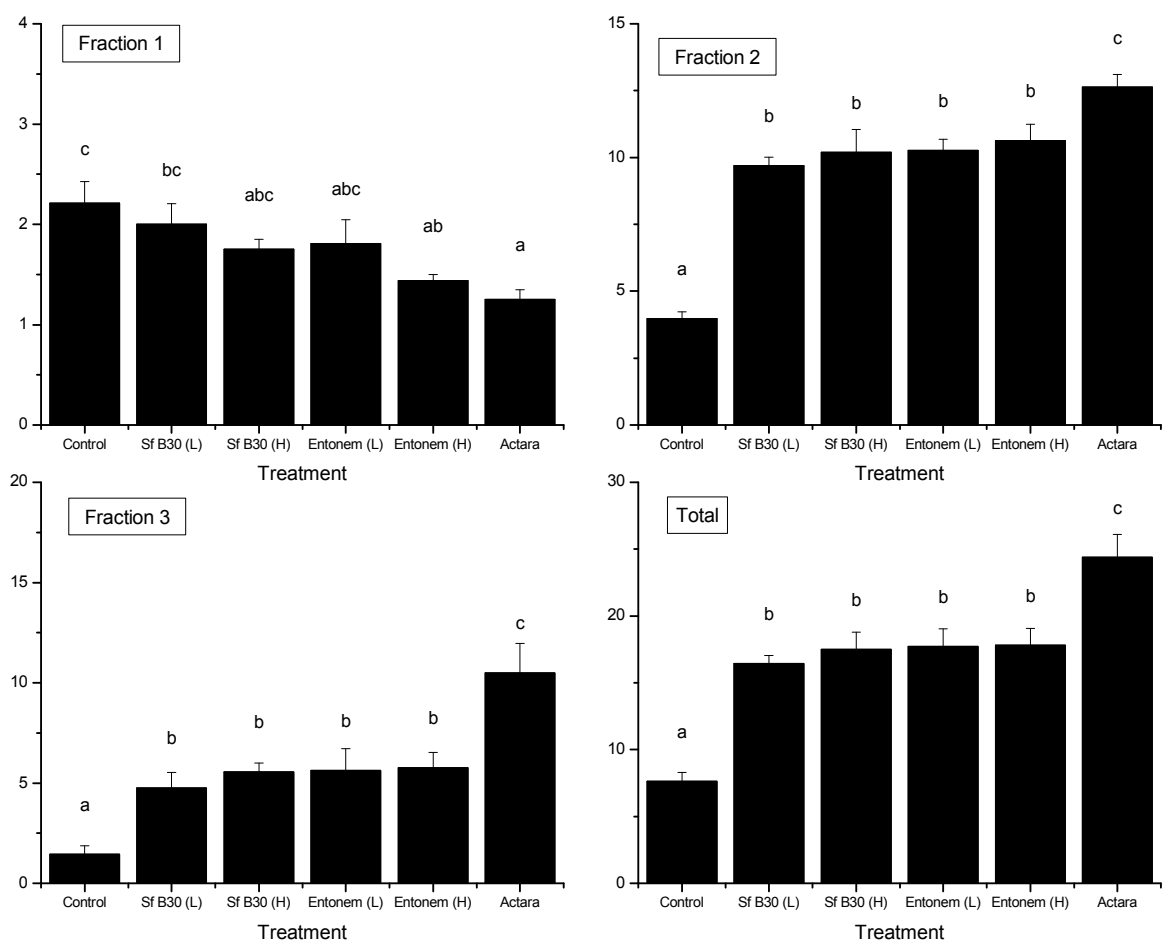

Fig. 1. Potato yield at different fractions and treatments in $2008 \mathrm{in} t /$ ha (Fraction 1: size of tubers $<4 \mathrm{~cm}$; Fraction 2: size of tubers between 4 and $5 \mathrm{~cm}$; Fraction 3: size of tubers $>5$ $\mathrm{cm})$. The letters above the columns represent statistically significant differences between individual treatments.

The population of Colorado potato beetles in our experiment increased with time, and the majority of damage was done in the middle of potato's growth period (the end of May, June and the beginning of July) (Maceljski et al., 2004), so we could reasonably expect loss of yield. We found out that more damaged plants (the control treatment) formed larger mass of smaller tubers, while the mass of larger tubers was smaller in the same treatment. The opposite was established in the treatments when plants were less damaged for a prolonged period of time and the formation of smaller tubers was not so intensive, while the mass of commercially more interesting (larger) tubers was higher. Total defoliation of potato influenced the development of tubers - sprouts formed ever anew, but they could not develop large tubers. The experiment confirmed the already known fact that the size of potato tubers is greatly influenced by the degree of success in suppressing larvae and adult specimens of Colorado potato beetles, since defoliation retards the development of tubers in soil (Mannan et al., 1992). Total defoliation of potato plants occurred at the end of the 
experiment in all treatments because the population of Colorado potato beetles on control blocks multiplied to the extent when it searched food (fresh potato leaves) in the immediate vicinity - this is consistent with the findings of related studies (Armer et al., 2004) in which the efficiency of Heterorhabditis marelatus Liu \& Berry against Colorado potato beetles was researched. Despite the fact that Welch and Briand (1961) warn against foliar application of EPNs, since nematode suspension on leaves dries to quickly and is thus less efficient, we maintain that by taking into account key limiting factors (temperature, moisture, UV radiation) (Kaya and Gaugler, 1993) and by the appropriate way of application satisfactory results can be reached also with the foliar use of EPN. This was confirmed also by some other studies (Broadbent and Olthof, 1995; Arthurs et al., 2004). The greatest difficulty in using such biological preparations is still their lesser efficiency in comparison with chemical preparations and high price (Ehlers, 1998).
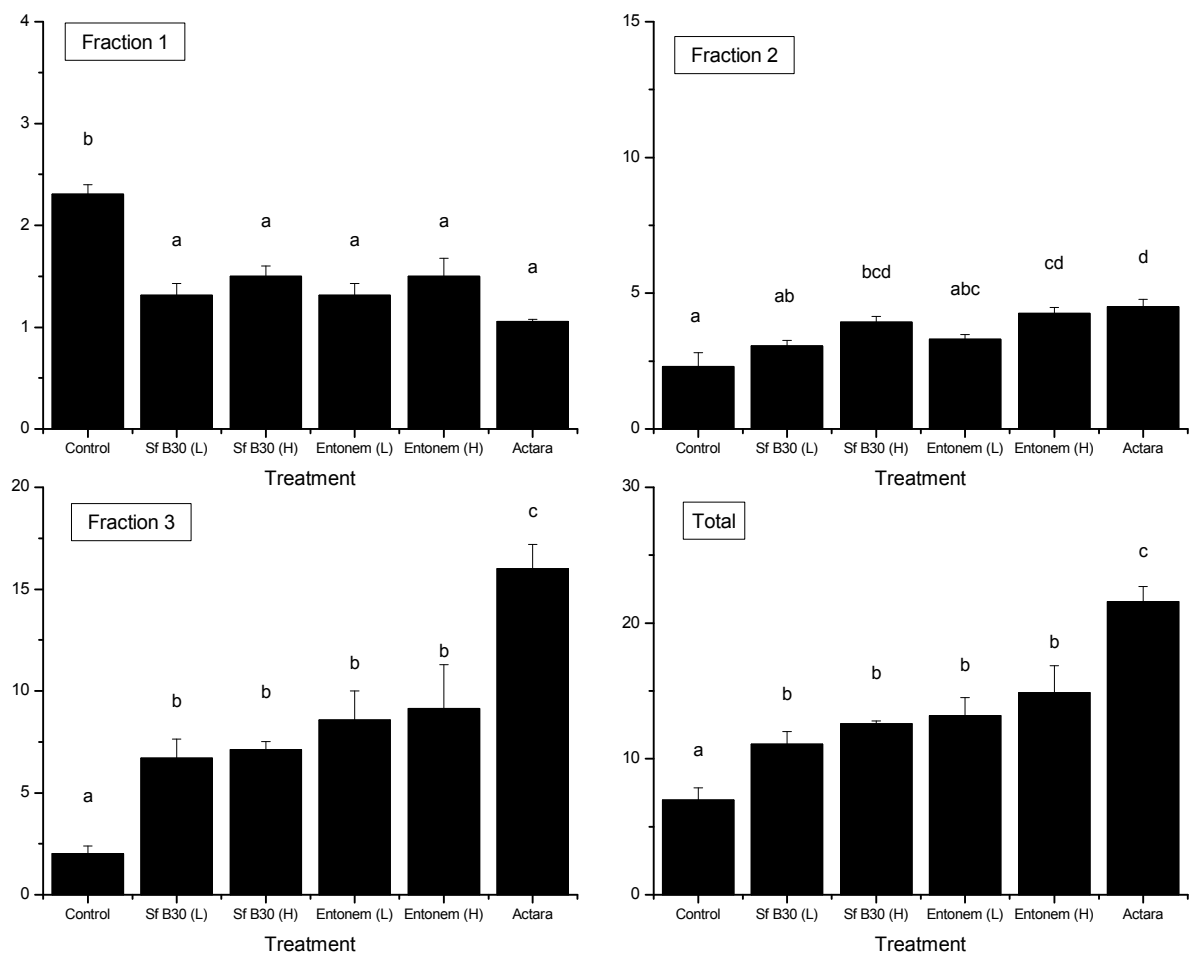

Fig. 2. Potato yield at different fractions and treatments in $2009 \mathrm{in} \mathrm{t} /$ ha (Fraction 1: size of tubers $<4 \mathrm{~cm}$; Fraction 2: size of tubers between 4 and $5 \mathrm{~cm}$; Fraction 3: size of tubers $>5$ $\mathrm{cm})$. The letters above the columns represent statistically significant differences between individual treatments.

\subsection{Cereal leaf beetle (Oulema melanopus [L.])}

The Cereal leaf beetle (Oulema melanopus) is widely spread in the world. In Europe it appears in all regions where cereals are grown, it is most widely spread in the Balkans and 
the neighbouring regions, especially in those with continental and moderate continental climate (Olfert et al., 2004). Beetles and larvae usually feed on the same hosts. The principal damage is caused by larvae, which feed on intervenous tissue on upper sides of leaves. This can cause $9.5 \%$ loss of yield. If 12 to $25 \%$ of leaf surface of wheat is destroyed, the yield is reduced by $14 \%$. When the upper leaf if completely destroyed, which is the most frequently attacked organ of cereals (the density of the harmful pest decreases from the top of plants), the yield may be reduced by up to $60 \%$ (Casagrande et al., 1977).

The results of our study, which researched effects of entomopathogenic nematodes in laboratory on adult specimens of the harmful pest (Laznik et al., 2010b), show that the mortality rates of the cereal leaf beetle imagos depends primarily on temperature, yet in connection with the concentration of nematode suspension, the nematode strain and the day after the treatment. All four studied strains caused the highest average mortality rates of specimens $(81 \%)$ six days after the treatment and at the highest concentration of nematode suspension (78 \%). The most efficient among the studied strains was S. carpocapsae C101, which is caused $96 \%$ mortality rate of beetles. The strain H. bacteriophora D54, on the other hand, caused only $49 \%$ mortality rate in the studied insects. The comparison between the two strain of $S$. feltiae shows that the commercial preparation Entonem is more efficient than the Slovenian strain B30 (67 \% and $54 \%)$. At 15 and $20^{\circ} \mathrm{C}$ we recorded lower mortality rate of beetles than at $25^{\circ} \mathrm{C}$, which coincides with the Slovenian studies so far (Trdan et al., 2008, 2009), while the strain H. bacteriophora D54 caused the highest mortality rate at higher temperatures. This too coincides with the results of the related studies (Trdan et al., 2008).

For imagos of cereal leaf beetles which hibernate and are in spring the first to appear on cereals, it is advisable to apply suspensions of nematodes $S$. feltiae and S. carpocapsae, since our experiment shows that these species reach highest efficiency at $15{ }^{\circ} \mathrm{C}$. The first adult specimens appear in Middle and South Europe in the first half of April, when nights are still relatively fresh (Stamenković, 2004). In our experiment the high concentration of nematode suspension proved to be most efficient, though relatively satisfactory efficiency was observed also at lower concentrations (from 53 to $65 \%$ ).

On the basis of our study's results we can conclude that efficiency of EPNs depends more on the temperature than on the concentration of nematode suspension, but it seems that the influence of concentration is species-specific (Arthurs et al., 2004). The data show that some species of nematodes functioned equally well at both lower and higher concentration. This is from the aspect of economic use of entomopathogenic nematodes particularly important. We should not, however, neglect the important fact that laboratory results are not always comparable with field experiments (Cantelo and Nickle, 1992), since the efficiency EPNs outdoors depends on many other factors and interaction between them. In a similar experiment S. carpocapsae was $100 \%$ efficient in suppressing larvae, pupae and adult specimens of Colorado potato beetles, while it reached only $31 \%$ efficiency when its activity was tested outdoors (Stewart et al., 1998).

\subsection{Common cockchafer (Melolontha melolontha [L.])}

In Slovenia, common cockchafer (Melolontha melolontha [L.]) is one of the most economically important pest of grasslands. Control of common cockchafer is feasible with the application of insecticide. However, due to the appearance of insect resistance, efficacy decrease owing to soil microorganisms activity and doubts on environmentally acceptability of such kind products, alternative solution are sought for its control (Koppenhöfer and Kaya, 1998). 
Results of our laboratory research (Laznik et al., 2009d) demonstrated that indigenous strain S. feltiae C76 attained higher mortality rate $(27 \%)$ of third-stage larvae of common cockchafer than commercial product Entonem (20\%). In a similar research, Berner and Schnetter (2001) reported on $3 \%$ larval mortality when S. feltiae strain Ehlers was applied and that as the best nematode in their experiment proved to be S. glaseri strain RS92 (60\%). Reason for poorer activity of $S$. feltiae we can attribute to the fact, that it goes for the species which has not been found in naturaly infected white grubs as this is documented for $S$. anomali (Kozodoi) S. glaseri (Steiner), S. kushidai (Mamiya), S. scarabaei (Stock), and Heterorhabditis megidis (Poinar) (Poinar, 1975).

Differences between strains studied in our experiment can be found due to the fact that strain C76 is much bettter adapted to the larvae of common cockchafer as we confirmed its finding in the area (Laznik et al., 2009d), where in the past common cockchafer caused quite an extensive damage on grasslands (Urek and Milevoj, 1993). Grewal et al. (2004) came to similar conclusions, namely that different strains of the same EPN species might act differently on various insect pests. It was established multiple times that indigenous strains are more virulent from the exotic strains (Grewal et al., 2004).

In our experiment, the most promising activity demonstrated the strain $\mathrm{C} 67$ at $20{ }^{\circ} \mathrm{C}$ and at highest concentration of nematode suspension (53\%), meanwhile the highest effect of bioproduct Entonem was attained at $20{ }^{\circ} \mathrm{C}$ and at middle concentration of nematode suspension $(31 \%)$. At corresponding application S. feltiae can very satisfying control the younger larval stages of common cockchafer, but when compared to entomopathogenic fungus Beuveria brongniartii (Poženel, 2007), the efficacy of the nematodes is lower.

\section{Activity of entomopathogenic nematodes against stored products pests}

\subsection{Rice weevil (Sitophilus oryzae [L.])}

Rice weevil (Sitophilus oryzae [L.]) in the recent years represents one of the most important stored cereals pests in Europe (Stejskal et al., 2003). Some previous studies have shown that EPNs can be efficient biological agents for suppressing some species of stored products pests, such as Sitophilus granarius (L.) (Trdan et al., 2006), Tribolium confusum Jacquelin du Val (Athanassiou et al., 2007), Tenebrio molitor L., Tribolium castaneum (Herbst), Trogoderma variabile Ballion and Oryzaephilus surinamensis (L.) (Ramos-Rodriguez et al., 2006; Trdan et al., 2006). The results of our laboratory study, however, have shown that the mortality rates of adult specimen of rice weevil depend on temperature and concentrations of nematode suspension, as well as on the strain of nematodes (Laznik et al., 2010a). Similar findings were produced also by researchers in some related studies (Arthurs et al., 2004; Laznik et al., 2010b).

The lowest mortality rate was in our experiment noted at $30{ }^{\circ} \mathrm{C}$, at which temperature no strain exceeded $20 \%$ efficiency. Lower efficiency at high temperature can be attributed to the fact that the temperature interval in which EPN's activity is optimal ranges between 20 and $26{ }^{\circ} \mathrm{C}$ (Trdan et al., 2008; Laznik et al., 2010b), it is nonetheless a species-specific relation (Kaya and Gaugler, 1993). At the lowest temperature in the experiment $\left(15^{\circ} \mathrm{C}\right)$ the Slovenian strains of S. feltiae (B30 and B49) proved more efficient than the Hungarian strain 3162. The reason for lower efficiency lies also in the fact that the strain 3162 was isolated in Hungary, which has continental climate with higher average temperatures than Slovenia (Peel et al., 2007). This strain has during its evolution most probably adjusted to slightly higher temperatures. Similar conclusions were made also by Hazir et al. (2004), who found out that 
strains of EPNs isolated in warmer regions function more efficiently at higher temperatures that those isolated in colder regions.

\subsection{Granary weevil (Sitophilus granarius [L.]) and sawtoothed grain beetle (Oryzaephilus surinamensis [L.])}

The granary weevil, Sitophilus granarius (L.), and the sawtoothed grain beetle, Oryzaephilus surinamensis (L.), are listed among important pests of stored grain, the former being a primary pest (Ungsunantwiwat and Mills, 1985) spread mostly in moderate climate, and the latter being a typical cosmopolitan and a secondary pest (Trematerra et al., 2000). Both species feed on a variety of cereals or cereal products, although wheat and barley are among the most frequent sources of their nutrition (Schwartz and Burkholder, 1991).

The investigation demonstrated that entomopathogenic nematodes control the granary weevil adults more efficiently than they control the adults of the sawtoothed grain beetle. The application of S. feltiae, S. carpocapsae and H. bacteriophora at $20^{\circ} \mathrm{C}$ and $25{ }^{\circ} \mathrm{C}$ resulted in mortality rates of over $57 \%$ in the granary weevil beetles. Satisfactory results in the control of the sawtoothed grain beetle were achieved only at $20{ }^{\circ} \mathrm{C}$, with the percentage of mortality of the beetles ranging between 44 and $81 \%$. These outcomes partly agree with the results of some related works, where an optimal biological activity of $S$. carpocapsae, H. bacteriophora, and S. feltiae was determined in the temperature range from 22 to $24^{\circ} \mathrm{C}$ (Choo HoYul et al. 2002), from 22 to $26^{\circ} \mathrm{C}$ (Kaya and Gaugler, 1993), and at 25C (Belair et al., 2003), respectively. In higher concentrations (500 IJs/adult and more) entomopathogenic nematodes can be considered efficient biological agents to control the adults of $S$. granarius and $O$. surinamensis. The general impression is that the use of the highest nematode concentrations (2000 IJs/adult) is not economically justified. S. feltiae, S. carpocapsae and $H$. bacteriophora can be recommended for the storage pest control since they were the most effective in the control of both storage pests.

\section{Non-target effect of entomopathogenic nematodes}

Entomopathogenic nematodes have been proven effective in controlling some foliar pests (Trdan et al., 2007a; Laznik et al., 2010c; Laznik et al., 2011), but they do have some negative properties. Among these, the wide spectrum of their efficacy includes a negative influence on beneficial organisms (Hazir et al., 2004). Up to now, the studies on the non-target effects of entomopathogenic nematodes were performed on various species of non-target organisms, and a large range - from complete harmlessness to pronounced harmful effect was established (Bathon 1996; Farag 2002). The results of some field trials show a moderate influence of entomopathogenic nematodes on non-target arthropods or even the absence of such an effect (Georgis et al. 1991). Bathon (1996) reports that mortality can be observed among the non-target organisms, but the influence of these agents should be temporary and local and so only a part of the population is under attack. Georgis et al. (1991) demonstrated a negligible influence of entomopathogenic nematodes on non-target organisms if they are used only in short term pest control.

Farag (2002) reports a high mortality of the larvae of Coccinella undecimpunctata Linnaeus caused by Heterorhabditis taysearae Shamseldean and Steinernema carpocapsae strain S2 in a laboratory assay, so the author does not recommend the use of entomopathogenic nematodes when these predators are present on the plants in high number. Likewise, Heterorhabditis bacteriophora Poinar and Steinernema carpocapsae (Weiser) species were - under 
laboratory conditions - very harmful to the following predators: Coleomegilla maculata [De Geer], Olla v-nigrum [Mulsant], Harmonia axyridis [Pallas] and Coccinella septempunctata L. On the other side Shapiro-Ilan and Cottrell (2005) found the lady beetles to be substantially less susceptible to nematode infection compared with a known susceptible insect - the black cutworm (Agrotis ipsilon Hüfnagel).

Results of our investigation showed that larvae of the two-spotted lady beetle and green lacewing are susceptible to EPN attack under laboratory conditions. The mortality rate for the two-spotted lady beetle larvae at $25^{\circ} \mathrm{C}$ was over $93 \%$. The mortality rate for the green lacewing larvae at the both higher temperature was over $42 \%$. In the most cases $H$. bacteriophora and mixed suspension of S. feltiae and H. bacteriophora were the least nontargetly efficient agents in our research (Rojht et al., 2009).

\section{Possibilities for integrated plant protection with entomopathogenic nematodes in future?}

Entomopathogenic nematodes may be combined with other agricultural chemicals and control agents for variour purposes. Based on our research, we conclude that the benefits of utilizing EPNs combined fungicide can offer better control management of an IPM programme. EPNs can be applied with nearly all commercially available ground or aerial spray equipment, including pressurized sprayers, mist blowers, and electrostatic sprayers (Kaya and Gaugler, 1993). This offers a cost-effective alternative to pest control, while simultaneous application of fungicide and EPNs influence as well on fungi agents of plant diseases as on insects, and it saves time and at the same time money spent for controlling pest organisms (Kaya and Gaugler, 1993). For active ingredients azoxystrobin (Anand et al., 2008), propamocarb (Urban and Lebeda, 2007), and sulphur (Bassino et al., 1977) are well known their efficacy against cucumber downy mildew (Pseudoperonospora cubensis [(Berk. \& M.A. Curtis) Rostovzev]) and powdery mildew disease (Erysiphe cichoracearum DC). While several precedent research showed that EPNs when applied correctly act efficiently on some pests of cucumbers, for example western flower thrips (Frankliniella occidentalis Pergande) (Trdan et al., 2007), and on the greenhouse whitefly (Trialeurodes vaporariorum [Westwood]) (Laznik et al., 2011). Synchronous application of fungicide and EPNs in such examples for controlling the aforementioned pests is justifiable. Similar conclusions can also be drawn together when dealing with active ingredients metiram, copper hydroxide, and mancozeb, which control especially potato blight (Phytophthora infestans [Mont.] de Bary), lettuce downy mildew (Bremia lactucae Regel), wheat leaf blotch (Septoria tritici Thüm.), and early blight of tomatoes (Alternaria solani Sorauer) (Milus, 1994; Stepanović et al., 2009; Stevenson, 2009) in connection with some pest insects like the Colorado potato beetle (Leptinotarsa decemlineata [Say]), cabbage armyworm (Mamestra brassicae [L.]), barley wireworm (Agriotes fuscicollis Miwa), cereal leaf beetle (Oulema melanopus [L.]), the tomato leafminer (Tuta absoluta [Povolny]) for which some previous research showed that EPNs are very effective biological agents for their control (Batalla-Carrera et al., 2010; Laznik et al., 2010ab). Anyway, future implementation of synchronous application of EPNs and fungicides must be supported by field experiments, while results of laboratory experiments can not be transferred uncritically into conditions which hold for the environment.

It is well known that biological preparations at the moment represent only $1 \%$ of the world market for protection of plants against diseases, harmful pests and weeds (Dent, 2003). As much as $80 \%$ of all biological preparations are based on the active substance of the bacteria 
Bacillus thuringiensis (Bt). Many analysts are of the opinion that biological preparations could replace as much as $20 \%$ of chemical products available on the market which is worth 7 billion American dollars (Blum, 2002). The dismal fact is that industrial plants which produce biological preparations are still insufficiently equipped and not prepared to penetrate such a big and important market. Even greater problem is the lack of awareness on the part of food producers and consumers regarding the significance of biological control (Dent, 2003). The use of nature-friendly organisms in plant protection is at the moment limited, this is primarily due to the fact that general public is not familiar with the usefulness of entomopathogenic nematodes as a means of biological protection of plants, as well as to the prevailing opinion that they are not as efficient as chemical products.

\section{Conclusion}

The results of many foreign studies and the Slovenian studies presented in this chapter prove that entomopathogenic nematodes are, when applied in optimal conditions, efficient agents for suppressing harmful pests (Kaya and Gaugler, 1993). Of course we must be aware that they are in general not as efficient as chemical insecticides, although some studies have also shown that appropriate applications of entomopathogenic nematodes can provide mortality rates of target harmful pests which are comparable with mortality rates of organisms exposed to synthetic insecticides (Laznik et al., 2011). When deciding to use entomopathogenic nematodes or even implementing them into the systems of food production, our expectations should not be the same as when using conventional protection of plants. We particularly should not focus solely on greater yields, but also bear in mind that using the said agents is acceptable for food, man and nature. In this case we should be prepared to tolerate slightly less attractive appearance of plants grown for food or decoration. At present we no longer have insecticides for suppressing many harmful insects, this means that circumstances are exceptionally favourable to increase the use of natural enemies and other forms biological protection of plants, and entomopathogenic nematodes are in this regard one of the most efficient alternatives to insecticides. The results of foreign and Slovenian studies show that these agents deserve to be given a try!

\section{Acknowledgement}

This chapter was performed under the projects L4-6477 and V4-0524, funded by the Slovenian Research Agency and Ministry of Agriculture, Food, and Forestry of the Republic of Slovenia, project V4-1067, funded by the Slovenian Research Agency, Ministry of Agriculture, Food, and Forestry of the Republic of Slovenia and Ministry of the Environment and Spatial Planning of Republic of Slovenia, and the programme Horticulture (P4-0013) funded by the Slovenian Research Agency. Part of the researches presented in this chapter was funded within Professional Tasks from the Field of Plant Protection, a program funded by the Ministry of Agriculture, Forestry, and Food of Phytosanitary Administration of the Republic of Slovenia, and within bilateral cooperation in science and technology between Slovenia and Hungary in the period 20082011. We thank Dr. Matej Vidrih, Dr. Filip Vučajnk, Dr. Dragan Žnidarčič, Dr. Tamas Lakatos, Dr. Timea Tóth, Jaka Rupnik, Aleksander Bobnar, Helena Rojht MSc, Melita Štrukelj, Sanja Ljubi, Luka Kužnik, Alenka Zupančič, Petra Premrl, and Nevenka Valič for technical assistance. 


\section{References}

Abbott, W.S. 1925: A method of computing the effectiveness of an insecticide. Journal of Economic Entomology, 18: 265-267.

Ábrahám E.B., Zsom E., Sárvári M. 2006. The effect of year and irrigation on the yield quantity and quality of the potato. Journal of Agricultural Sciences, 24: 12-16

Akhurst R. J. 1980. Morphological and functional dimorphism in Xenorhabdus spp., bacteria symbiotically associated with the insect pathogenic nematodes Neoaplectana and Heterorhabditis. Journal of General Microbiology, 121: 303-309

Anand T., Chandrasekaran A., Pillai-Kuttalam S., Senthilraja G., Raguchander T., Samiyappan R. 2008. Effectiveness of azoxystrobin in the control of Erysiphe cichoracearum and Psedoperonospora cubensis on cucumber. Journal of Plant Protection Research, 48: 147-158.

Armer C.A., Berry R.E., Reed G.L., Jepsen S.J. 2004. Colorado potato beetle control by application of the entomopathogenic nematode Heterorhabditis marelata and potato plant alkaloid manipulation. Entomologia Experimentalis et Applicata, 111: 47-58

Arthurs S., Heinz K.M., Prasifka J.R. 2004. An analysis of using entomopathogenic nematodes against above-ground pests. Bulletin of Entomological Research, 94: 297-306

Athanassiou C.G., Palyvos N.E., Kakouli-Duarte T. 2007. Insecticidal effect of Steinernema feltiae (Filipjev) (Nematoda: Steinernematidae) against Tribolium confusum du Val (Coleoptera: Tenebrionidae) and Ephestia kuehniella (Zeller) (Lepidoptera: Pyralidae) in stored wheat. Journal of Stored Product Research, 44: 52-57

Athanassiou, C.G., Kavallieratos, N.G., Menti, H., Karanastasi E. 2010. Mortality of four stored product pests in stored wheat when exposed to doses of three entomopathogenic nematodes. Journal of Economic Entomology 103: 977-984.

Bassino J.-P., Bailly R., Blanc M., Pascal C. 1977. Powdery mildew of melon. The efficiency of various products. Defense des Vegetaux 31: 151-157.

Batalla-Carrera L., Morton A., Garcia del Pino F. 2010. Efficacy of entomopathogenic nematodes against the tomato leafminer Tuta absoluta in laboratory and greenhouse conditions. BioControl 55: 523-530.

Bathon H. 1996. Impact of entomopathogenic nematodes on non-target hosts. Biocontrol Science and Technology, 6: 421-434

Bedding R.A., Akhurst R.J. 1975. A simple technique for the detection of insect parasitic rhabditid nematodes in soil. Nematologica, 21: 109-110

Bednarek A., Nowicki T. 1986. Effect of intrapopulation factors in the nematodes Steinernema feltiae (Steinernematidae) on the intensity of insect infestation. Zeszyty Problemowe Postepow Nauk Rolniczych, 323: 199-212

Belair, G., Fournier, Y., Dauphinais, N. (2003): Efficacy of steinernematid nematodes against three insect pests of crucifers in Quebec. Journal of Nematology, 35, 259-265.

Berner, M., Schnetter, W. 2001. Wirksamkeit entomopathogener Nematodes gegen Engerlinge der Maikäfer Melolontha melolontha und M. hippocastani. Mitt. Dtsch. Ges. Allg. angew. Entomol. 13: 165-167.

Blum, B. 2002. Blocked opportunities for bio-control. Pesticide News 57, September 2002.

Boemare, N.E., Akhurst, R.J., Mourant, R.G. 1993. DNA relatedness between Xenorhabdus spp. (Enterobacteriaceae), symbiotic bacteria of entomopathogenic nematodes, and 
a proposal to transfer Xenorhabdus luminescens to a new genus, Photorhabdus gen. Nov. International Journal of Systematic Bacteriology, 43: 249-255.

Boemare N.E., Laumond C., Luciani J. 1982. Mise en evidence d'une toxicogenese provoquee par le nematode entomophage Neoplectana carpocapsae Weiser chez l'insecte Galleria mellonella L. Compets Rendus des séances de l'Academie des Scences, Paris, Ser. III. 295: 543-546

Bovien, P. 1937. Some type of association between nematodes and insects. Videnk. Meddr Naturh. Foren. 101: 1-114.

Broadbent A. B., Olthof T. H. A. 1995. Foliar application of Steinernema carpocapsae (Rhabditida: Steinernematidae) to control Liriomyza trifolii (Diptera: Agromyzidae) larvae in chrysanthemums. Environmental Entomology, 24: 431-435

Campbell J. F., Lewis E. E., Stock S. P., Nadler S., Kaya H. K. 2003. Evolution of host search strategies in entomopathogenic nematodes (Nematoda: Steinernematidae). Journal of Nematology, 35: 142-145

Cantelo W.W., Nickle W.R. 1992. Susceptibility of prepupae of the Colorado potato beetle (Coleoptera: Chrysomelidae) to entomopathogenic nematodes (Rhabditida: Steinernematidae, Heterorhabditidae). Journal of Entomological Science, 27: 37-43

Cantliffe, D.J., Funes, J., Jovicich, E., Paranjpe, A., Rodriguez, J., Shaw, N. 2003. Media and containers for greenhouse soilless grown cucumbers, melons, peppers and strawberries. Acta Horticulturae 614: 199-203.

Casagrande R.A., Ruesink W.G., Haynes D.L. 1977. The behaviour and survival of adult cereal leaf beetles. Annals of the Entomological Society of America, 70: 19-30

Chavarría-Hernandez, N., M. de la Torre, 2001: Population growth kinetics of the nematode, Steinernema feltiae, in submerged monoxenic culture. Biotechnol. Lett. 23, 311-315.

Choo HoYul, Lee DongWoon, Yoon HeeSook, Lee SangMyeong, Hang DaoThi, 2002. Effects of temperature and nematode concentration on pathogenicity and reproduction of entomopathogenic nematode, Steinernema carpocapsae Pocheon strain (Nematoda: Steinernematidae). Korean Journal of Applied Entomology, 41, 269-277.

Chyzik, R., Glazer, J., Klein, M. 1996. Virulence and efficacy of different entomopathogenic nematode species against western flower thrips (Frankliniella occidentalis). Phytoparasitica 24: 103-110.

Coffin, R.S., Coutts, R.H.A. 1995. Relationships among Trialeurodes vaporariorum-transmitted yellowing viruses from Europe to North America. J. Phytopathol. 143: 375-380.

Cranshaw W.S., Radcliffe E.B. 1980: Effect of defoliation on yield of potatoes. Journal of Economic Entomology, 73: 131-134

De Nardo, E.A.B., Grewal, P.S., 2003. Compatibility of Steinernema feltiae (Nematoda: Steinernematidae) with Pesticides and Plant Growth Regulators Used in Glasshouse Plant Production. Biocontrol Sci. Technol. 13, 441-448.

Dent, D. 2003. Can biological control replace chemicals? Edited presentation to the Pesticide Challenge conference.

Ehlers R.-U. 2001. Mass production of entomopathogenic nematodes for plant protection. Applied Microbiology and Biotechnology, 56: 523-633

Fan, X., Hominick, W.M. 1991. Efficiency of the Galleria (wax moth) baiting technique for recovering infective stages of entomopathogenic rhabditids (Steinernematidae and Heterorhabditidae) from sand and soil. Rev. Nematol., 14: 381-387. 
Farag N. A. 2002. Impact of two entomopathogenic nematodes on the ladybird, Coccinella undecimpunctata and its pray, Aphis fabae. Ann. Agric. Sci. (Cairo). Fac. Agric., Ain Shams Univ., Cairo, Egypt, 47: 431-443

Fischer-Le Saux M., Mauléon H., Constant P., Brunel B., Boemare N.E. 1998. PCR-ribotyping of Xenorhabdus and Photorhabdus isolates from the Caribbean region in relation to the taxonomy and geographic distribution of their nematode hosts. Applied Environmental Microbiology, 64: 4246-4254

Flanders, K.L., Miller, J.M., Shields, E.J. 1996. In vivo production of Heterorhabditis bacteriophora »Oswego« (Rhabditida: Heterorhabditidae), a potential biological control agent for soil-inhabiting insects in temperate regions. Journal of Economic Entomology, 89: 373-380.

Forst S., Clarke D., 2002. Bacteria-nematode symbiosis. In: Entomopathogenic Nematology. Gaulger R. (ed.). Wallingford, UK, CABI Publishing: 57-77

Georgis R., Kaya H. K., Gaugler R. 1991. Effect of steinernematid and heterorhabditid nematodes (Rhabditida: Steinernematidae and Heterorhabditidae) on nontarget arthropods. Environmental Entomology, 20: 815-822

Glaser, R.W., Farrell, C.C. 1935. Field experiments with the Japanese beetle and its nematode parasite. Journal of New York Entomological Society 43: 345.

Glaser R W., Fox H. 1930. A nematode parasite of the Japanese beetle (Popillia japonica Newm). Science, 71: 1617

Gorman, K., Hewitt, F., Denholm, I., Devine, G.J. 2001. New developments in insecticide resistance in the glasshouse whitefly (Trialeurodes vaporariorum) and the twospotted spider mite (Tetranychus urticae) in the UK. Pest Management Science 58, 123-130.

Grewal, P.S., 2002. Formulation and application technology. In: Entomopathogenic Nematology CABI Publishing (Gaugler, R., Ed.) vol. 15. CAB International, Wallingford, 311-332.

Grewal, P.S., Power, K.T., Grewal, S.K., Suggars, A., Haupricht, S. 2004. Enhanced consistency in biological control of white grubs (Coleoptera: Scarabaeidae) with new strains of entomopathogenic nematodes. Biological Control 30: 73-82.

Grewal P.S., Ehlers R.-U., Shapiro-Ilan D.I. 2005. Nematodes as biocontrol agents. Wallingford, UK, CABI Publishing: 505 str.

Hare J.D. 1980. Impact of defoliation by the Colorado potato beetle on potato yields. Journal of Economic Entomology, 73: 369-373

Hara, A.H., Kaya, H.K., Gaugler, R., Lebeck, L.M., Mello, C.L. 1993. Entomopathogenic nematodes for biological control of leafminer, Liriomyza trifolii (Diptera: Agromyzidae). Entomophaga 38: 359-369.

Hazir S., Kaya H. K., Stock S.P., Keskin N. 2004. Entomopathogenic nematodes (Steinernematidae and Heterorhabditidae) for biological control of soil pests. Turkish Journal of Biology, 27: 181-202

Hoffmann E.J., Middleton S.M., Wise J.C. 2008. Ovicidal activity of organophosphate, oxadiazine, neonicotinoid and insect growth regulator chemistries on northern strain plum curculio, Conotrachelus nenuphar. Journal of Insect Science, 8: 1536-2442

Hominick W.M. 2002. Biogeography. V: Entomopathogenic Nematology. Gaugler R (ed). Wallingford, UK, CABI Publishing:115-143 
Hominick W.M., Briscoe B.R., del Pino F.G., Heng J., Hunt D.J., Kozodoy E., Mracek Z., Nguyen K.B., Reid A.P., Spiridonov S., Stock P., Sturhan D., Waturu C., Yoshida M. 1997. Biosystematics of entomopathogenic nematodes: current status, protocols and definitions. Journal of Helminthology, 71: 271-298.

Ishibashi N., Choi D.-R. 1991. Biological control of soil pests by mixed application of entomopathogenic and fungivorous nematodes. Journal of Nematology, 23: 175-181

Kaya H. K., Gaugler R. 1993. Entomopathogenic nematodes. Annual Review of Entomology, 38: 181-206

Koppenhöfer, A.M., Cowles, R.S., Cowles, E.A., Fuzy, E.M., Baumgartner, L., 2002. Comparison of neonicotinoid insecticides as synergists for entomopathogenic nematodes. Biol. Control 24, 90-97.

Koppenhöffer A.M., Fuzy E.M., Crocker R., Gelernter W., Polavarapu S. 2004. Pathogenicity of Steinernema scarabaei, Heterorhabditis bacteriophora and S. glaseri to twelve white grub species. Biocontrol Science and Technology, 14: 87-92

Koppenhöfer, A.M., Kaya, H.K. 1998. Synergism of imidacloprid and an entomopathogenic nematode: A novel approach to white grub (Coleoptera: Scarabaeidae) control in turfgrass. Journal of Economic Entomology, 91: 618-623.

Laznik Ž., Trdan S. 2008a. Entomopathogenic and entomoparasitic nematodes as biological control agents of thrips. Acta Phytopathologica et Entomologica Hungarica, 43: 317-322

Laznik Ž., Trdan S. 2008b. Entomopathogenic nematodes, natural enemies of foliar pests of vegetable brassicas. Acta agriculturae Slovenica, 91: 227-237 [Slovenian]

Laznik Ž., Tóth T., Lakatos T., Trdan S. 2008. Entomopathogenic nematode Steinernema carpocapsae (Weiser) (Rhabditida: Steinernematidae), a new member of Slovenian fauna. Acta agriculturae Slovenica, 91: 351-359

Laznik Ž., Tóth T., Lakatos T., Vidrih M., Trdan S. 2009a. First record of Steinernema feltiae (Filipjev) (Rhabditida: Steinernematidae) in Slovenia. Helminthologia, 46:135-138

Laznik Ž., Tóth T., Lakatos T., Vidrih M., Trdan S. 2009b. First record of a cold active entomopathogenic nematode Steinernema kraussei (Steiner) (Rhabditida: Steinernematidae) in Slovenia. Acta agriculturae Slovenica, 93: 37-42

Laznik Ž., Tóth T., Lakatos T., Trdan S. 2009c. Heterorhabditis bacteriophora (Poinar) - the first member from Heterorhabditidae family in Slovenia. Acta agriculturae Slovenica, 93: 181-187

Laznik Ž., Tóth T., Lakatos T., Vidrih M., Trdan S. 2009d. Efficacy of two strains of Steinernema feltiae (Filipjev) (Rhabditida: Steinernematidae) against third-stage larvae of common cockchafer (Melolontha melolontha [L.], Coleoptera, Scarabaeidae) under laboratory conditions. Acta Agriculturae Slovenica, 93: 293-299

Laznik Ž., Tóth T., Lakatos T., Vidrih M., Trdan S. 2010a. The activity of three new strains of Steinernema feltiae against adults of Sitophilus oryzae under laboratory conditions. Journal of Food, Agriculture and Environment, 8: 132-136

Laznik Ž., Tóth T., Lakatos T., Vidrih M., Trdan S. 2010b. Oulema melanopus (L.) (Coleoptera: Chrysomelidae) adults are susceptible to entomopathogenic nematodes (Rhabditida) attack: results from a laboratory study. Journal of Plant Diseases and Protection, 117: 30-32

Laznik Ž., Tóth T., Lakatos T., Vidrih M., Trdan S. 2010c. Control of the Colorado potato beetle (Leptinotarsa decemlineata [Say]) on potato under field conditions: a 
comparison of the efficacy of foliar application of two strains of Steinernema feltiae (Filipjev) and spraying with thiametoxam. Journal of Plant Diseases and Protection, 117: 129-135

Laznik Ž., Žnidarčič D., Trdan S. 2011. Control of Trialeurodes vaporariorum (Westwood) adults on glasshouse-grown cucumbers in four different growth substrates: an efficacy comparison of foliar application of Steinernema feltiae (Filipjev) and spraying with thiamethoxam. Turkish Journal of Agriculture and Forestry, 35 (in press)

LeBeck L. M., Gaugler R., Kaya H. K., Hara A. H., Johnson M. W. 1993. Host stage suitability of the leafminer Liriomyza trifolii (Diptera: Agromyzidae) to the entomopathogenic nematode Steinernema carpocapsae (Rhabditida: Steinernematidae). Journal of Invertebrate Pathology, 62: 58-63

Long S.J., Richardson P.N., Fenlon J.S. 2000. Influence of temperature on the infectivity of entomopathogenic nematodes (Steinernema and Heterorhabditis spp.) to larvae and pupae of the vine weevil Otiorhynchus sulcatus (Coleoptera: Curculionidae). Nematology, 2: 309-317

Maceljski, M., Cvjetković, B., Ostojić, Z., Igrc-Barčić, J., Pagliarini, N., Oštrec, L., Barić, K., Čizmić, I. 2004. Štetočinje povrća s opsežnim prakazom zaštite povrća od štetnika, uzročnika bolesti i korova. Čakovec, Zrinski: 517 pp.

Mannan M.A., Bhuiyan M.K.R., Quasem A., Rashid M.M., Siddique M.A., 1992. Study on the growth and partitioning of dry matter in sween potato. Journal of Root Crops, 18: $1-5$

Mráček, Z., Bečvář, S. 2000. Insect aggregations and entomopathogenic nematode occurence. Nematology, 2: 297-301.

Milevoj L. 1998. Perspektive biotičnega varstva rastlin v Sloveniji. In: Zbornik posveta Kmetijstvo in okolje. Rečnik M. (ur.) in Verbič J. (eds.). Ljubljana, Kmetijski inštitut Slovenije: $163-171$

Milevoj L. 2002. Biotično varstvo solatnic. Sodobno kmetijstvo, 33: 282-283

Milošević D., Djalović I., Bugarčić Z. 2008. The importance of a healthy planting material for potato production increases. Agro-knowledge Journal, 9: 5-17

Milus E.A., 1994. Effect of foliar fungicides on disease control, yield and test weight of soft red winter wheat. Crop Protection, 13: 291-295.

Nielsen O., Philipsen H. 2004. Occurrence of Steinernema species in cabbage fields and the effect of inoculated S. feltiae on Delia radicum and its parasitoids. Agricultural and Forest Entomology, 6: 25-30

O'Halloran D.M., Burnell A.M. 2002. Olfaction and odour discrimination in the insect parasitic nematode Heterorhabditis bacteriophora. Nematology, 4: 206

Olfert O., Weiss R.M., Woods S., Philip H., Dosdall L. 2004. Potential distribution and relative abundance of an invasive cereal crop pest, Oulema melanopus L. (Coleoptera: Chrysomelidae), in Canada. The Canadian Entomologist, 136: 277-287

Peel M.C., Finlayson B.L., McMahon T.A. 2007. Updated world map of the Köppen-Geiger climate classification. Hydrology and Earth System Sciences, 11: 1633-1644

Perme S. 2005. Testing the efficacy of entomopathogenic nematodes (Rhabditida) against foliar pests of vegetables. Master Thesis, University of Ljubljana, Biotechnical faculty: 89 pp.

Poinar, G.O. Jr. 1975. Entomogenous Nematodes. E.J. Brill, Leiden, The Netherlands: 317 pp. 
Poinar G.O. 1988. Redescription of Neoaplectana affinis Bovien (Rhabditida: Steinernematidae). Revue de Nematology, 11: 143-147

Poinar, G.O. Jr. 1993. Origins and phylogenetic relationships of the entomophilic rhabditids, Heterorhabditis and Steinernema. Fundamental and Applied Nematology, 16: 333338.

Poženel, A. 2007. Experiences in controlling common cockchafer (Melolontha melolontha L.) in Idrija region. Lect. pap. present. 8th Slov. Conf. Plant Prot., Radenci, March 6-7 2007. Ljubl., Plant Prot. Soc. Slov.: $72-77$ [Slovenian]

Pravilnik o biotičnem varstvu rastlin. 2006. Ur. 1. RS št. 45/06

Premachandra, W. T. S. D., Borgemeister, C., Berndt, O., Ehlers, R.-U., Poehling, H.-M., 2003. Laboratory bioassays of virulence of entomopathogenic nematodes against soilinhabiting Frankliniella occidentalis Pergande (Thysanoptera: Thripidae). Nematology 5: 539-547.

Ramos-Rodriguez O., Campbell J.F., Ramaswamy S.B. 2006. Pathogenicity of three species of entomopathogenic nematodes to some major stored-product insect pests. Journal of Stored Product Research, 42: 241-252

Rojht, H., Kač, M. \& Trdan, S. 2009: Nontarget effect of entomopathogenic nematodes on larvae of twospotted lady beetle (Coleoptera: Coccinellidae) and green lacewing (Neuroptera: Chrysopidae) under laboratory conditions. Journal of Economic Entomology, 102 (4): 1440-1443.

Rovesti, L., Deseo, K.K., 1990. Compatibility of chemical pesticides with entomopathogenic nematodes Steinernema carpocapsae Weiser and S. feltiae Filipjev (Nematoda: Steinernematidae). Nematologica 36: 237-245.

Schwartz B.E., Burkholder, W.E. (1991): Development of the granary weevil (Coleoptera: Curculionidae) on barley, corn, oats, rice, and wheat. Journal of Economic Entomology, 84, 1047-1052.

Shapiro-Ilan D.I., Cottrell T. E. 2005. Susceptibility of lady beetles (Coleoptera: Coccinellidae) to entomopathogenic nematodes. Journal of Invertebrate Pathology, 89: 150-156

Sher, R.B., Parella, M.P. 1999. Biological control of the leafminer, Liriomyza trifolii, in chrysanthemums: implications for intraguild predation between Diglyphus begini and Steinernema carpocapsae. Bulletin of the International Organization for Biological and Integrated Control of Noxious Animals and Plants: Integrated Control in Glasshouses, 22: 221-224.

Sklep o spremembi statusa tujerodnega organizma za biotično varstvo rastlin: št. 34309/2008/5. 2008a. Ljubljana, Ministrstvo za kmetijstvo; gozdarstvo in prehrano: 2 pp. (internal material)

Sklep o spremembi statusa tujerodnega organizma za biotično varstvo rastlin: št. 3430583/2008/2. 2008b. Ljubljana, Ministrstvo za kmetijstvo; gozdarstvo in prehrano: 2 pp. (internal material)

Sklep o spremembi statusa tujerodnega organizma za biotično varstvo rastlin: št. 34302/2009/2. 2009a. Ljubljana, Ministrstvo za kmetijstvo; gozdarstvo in prehrano: 2 pp. (internal material)

Sklep o spremembi statusa tujerodnega organizma za biotično varstvo rastlin: št. 343012/2009/2. 2009b. Ljubljana, Ministrstvo za kmetijstvo; gozdarstvo in prehrano: 2 pp. (internal material) 
Stamenković S. 2004. Occurrence and damage of cereal leaf beetle (Oulema melanopus L.). Biljni lekar, 32: 124-127

Statistični urad Republike Slovenije 2005. http:/ / www.stat.si (28.1.2011)

Stejskal V., Hubert J., Kučerová Z., Munzbergová Z., Lukaš J., Žd'árková E. 2003. The influence of the type of storage on pest infestion of stored grain in the Czech Republic. Plant Soil and Environment, 49: 55-62

Stepanović M., Vuksa P., Potočnik I., Milijašević S., Rekanović E., Todorović B. 2009. Integrated management of viral sensitivity of Alternaria solani isolatess to some fungicides. Acta Horticulturae 808: 377-380.

Stevenson W.R. 2009. Late blight control strategies in the United States. Acta Horticulturae 834: 83-86.

Stewart J.G., Boiteau G., Kimpinski J. 1998. Management of late-season adults of the Colorado potato beetle (Coleoptera: Chrysomelidae) with entomopathogenic nematodes. The Canadian Entomologist, 130: 509-514

Sturhan D. 1996. Seasonal occurrence, horizontal and vertical dispersal of entomopathogenic nematodes in a field. Mitteilungen aus der Biologischen Bundesanstalt fur Landund Forstwirtschaft, 317: 35-45

Tokumaru, S., Abe, Y. 2005. Effects of host plants on the development and host preference of Liriomyza sativae, L. trifolii and L. bryoniae (Diptera: Agromyzidae). Japanese Journal of Applied Entomology and Zoology 49: 135-142.

Trdan S., Vidrih M., Valič N. 2006. Activity of four entomopathogenic nematode species against young adults of Sitophilus granarius (Coleoptera: Curculionidae) and Oryzaephilus surinamensis (Coleoptera: Silvanidae) under laboratory conditions. Journal of Plant Diseases and Protection, 113: 168-173

Trdan S., Žnidarčič D., Vidrih M. 2007a. Control of Frankliniella occidentalis on glasshousegrown cucumbers: an efficacy comparison of foliar application of Steinernema feltiae and spraying with abamectin. Russian Journal of Nematology, 15: 25-34

Trdan, S., Kužnik, L. \& Vidrih, M. 2007b: First results concerning the efficacy of entomopathogenic nematodes against Hercinothrips femoralis (Reuter). Acta agriculturae Slovenica, 89: 5-13.

Trdan S., Vidrih M., Valič N., Laznik Ž. 2008. Impact of entomopathogenic nematodes on adults of Phyllotreta spp. (Coleoptera: Chrysomelidae) under laboratory conditions. Acta Agriculturae Scandinavica, B Soil Plant Science, 58: 169-175

Trdan S., Vidrih M., Andjus L., Laznik Ž. 2009. Activity of four entomopathogenic nematode species against different developmental stages of Colorado potato beetle, Leptinotarsa decemlineata (Coleoptera, Chrysomelidae). Helminthologia, 46: 14-20

Trematerra, P., Sciarreta, A., Tamasi, E. (2000): Behavioural responses of Oryzaephilus surinamensis, Tribolium castaneum and Tribolium confusum to naturally and artificially damaged durum wheat kernels. Entomologia Experimentalis et Applicata 94: 195-200.

Ungsunantwiwat, A., Mills, R.B. (1985): Influence of rearing medium on size and weight of adults of four Sitophilus populations and on weight loss of host kernels (Coleoptera: Curculionidae). Journal of Stored Products Research, 21: 89-93.

Urban J., Lebeda A. 2007. Variation of fungicide resistance in Czech populations of Psedoperonospora cubensis. Journal of Phytopathology 155: 143-151.

Urek, G., Milevoj, L. 1993. Ogrčja nadloga: poljedelstvo: varstvo. Kmetovalec, 61: 7-8. 
Vet, L.E.M., van Lenteren, J.V., Woets, J. 1980. The parasite-host relationship between Encarsia formosa and Trialeurodes vaporariorum IX. A review of the biological control of the greenhouse whitefly with suggestion for future research. Zeitschrift für Angewandte Entomology, 90: 26-51.

Weiser, J. 1955. Neoaplectana carpocapsae n. sp. (Anguillulata, Steiner-nematidae) novy Cizopasnik housenek obatecejableeneho Carpocapsa pomonella L. Vestnik Ceskoslovenske Spoiecnosti Zooloaicke 19: 44-52.

Welch H.E., Briand L.J. 1961. Tests of the nematode DD136 and an associated bacterium for control of the Colorado potato beetle, Leptinotarsa decemlineata (Say). The Canadian Entomologist 93, 759-763

White, G. F. 1929: A method for obtaining infective nematode larvae from cultures. Science, 66: $302-303$

Willmott D.M., Hart A.J., Long S.J., Richardson P.N., Chandler D. 2002. Susceptibility of cabbage root fly Delia radicum, in potted cauliflower (Brassica oleracea var. botrytis) to isolates of entomopathogenic nematodes (Steinernema and Heterorhabditis spp.) indigenous to the UK. Nematology, 4: 965-970

Zupančič, A. 2008: Research on efficacy of entomopathogenic nematodes (Rhabditida) against cabbage stink bug (Eurydema ventrale Kolenati, Heteroptera, Pentatomidae). Graduation Thesis. Ljubljana: XI, 39 pp. [Slovenian] 


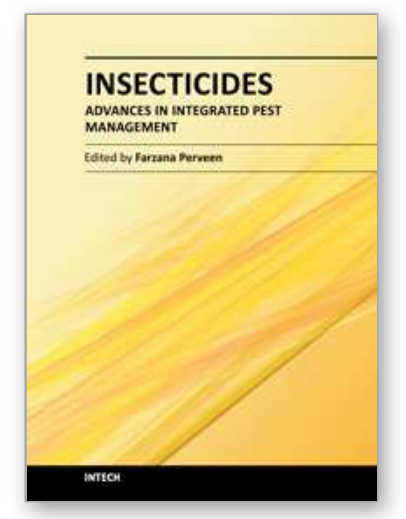

\author{
Insecticides - Advances in Integrated Pest Management \\ Edited by Dr. Farzana Perveen
}

ISBN 978-953-307-780-2

Hard cover, 708 pages

Publisher InTech

Published online 05, January, 2012

Published in print edition January, 2012

This book contains 30 Chapters divided into 5 Sections. Section A covers integrated pest management, alternative insect control strategies, ecological impact of insecticides as well as pesticides and drugs of forensic interest. Section B is dedicated to chemical control and health risks, applications for insecticides, metabolism of pesticides by human cytochrome p450, etc. Section $\mathrm{C}$ provides biochemical analyses of action of chlorfluazuron, pest control effects on seed yield, chemical ecology, quality control, development of ideal insecticide, insecticide resistance, etc. Section $D$ reviews current analytical methods, electroanalysis of insecticides, insecticide activity and secondary metabolites. Section E provides data contributing to better understanding of biological control through Bacillus sphaericus and B. thuringiensis, entomopathogenic nematodes insecticides, vector-borne disease, etc. The subject matter in this book should attract the reader's concern to support rational decisions regarding the use of pesticides.

\title{
How to reference
}

In order to correctly reference this scholarly work, feel free to copy and paste the following:

Ziga Laznik and Stanislav Trdan (2012). Entomopathogenic Nematodes (Nematoda: Rhabditida) in Slovenia: From Tabula Rasa to Implementation into Crop Production Systems, Insecticides - Advances in Integrated Pest Management, Dr. Farzana Perveen (Ed.), ISBN: 978-953-307-780-2, InTech, Available from: http://www.intechopen.com/books/insecticides-advances-in-integrated-pest-management/entomopathogenicnematodes-nematoda-rhabditida-in-slovenia-from-tabula-rasa-to-implementation-into-c

\section{INTECH}

open science | open minds

\section{InTech Europe}

University Campus STeP Ri

Slavka Krautzeka 83/A

51000 Rijeka, Croatia

Phone: +385 (51) 770447

Fax: +385 (51) 686166

www.intechopen.com

\section{InTech China}

Unit 405, Office Block, Hotel Equatorial Shanghai

No.65, Yan An Road (West), Shanghai, 200040, China

中国上海市延安西路65号上海国际贵都大饭店办公楼405单元

Phone: +86-21-62489820

Fax: $+86-21-62489821$ 
(C) 2012 The Author(s). Licensee IntechOpen. This is an open access article distributed under the terms of the Creative Commons Attribution 3.0 License, which permits unrestricted use, distribution, and reproduction in any medium, provided the original work is properly cited. 